\title{
Functional Li-M (Ti, Al, Co, Ni, Mn, Fe)-O Energy Materials
}

\author{
In Yea Kim, Seo Yoon Shin, Jea Hwan Ko, Kang Soo Lee*, Sung Pil Woo*, \\ Dong Kyu Kim, and Young Soo Yoon ${ }^{\dagger}$ \\ Department of Chemical and Biological Engineering, Gachon University, Seongnam 13120, Korea \\ *Department of Materials Science and Engineering, Yonsei University, Seoul 03722, Korea
}

(Received January 17, 2017; Accepted January 17, 2017)

\begin{abstract}
Many new functional materials have been studied for efficient production and storage of energy. Many new materials such as sodium-based and sulfide-based materials have been proposed for energy storage, but research on Li batteries is still dominant. Due to the influence of environmental concerns regarding nuclear energy, interest in and research on fusion power are steadily increasing. For the commercialization of nuclear fusion, a design standard based on a considerable level of physical analysis and modeling is proposed. Nevertheless, limitations of existing materials in nuclear fusion environments limit practical applications. Tritium propagation material for continuous fusion reaction is one of the core materials, and therefore research on this material is being carried out intermittently. The key material for Li-based energy storage and tritium generation is the functional material Li-M-O. In this review, a structural description of functional Li-M-O system materials and technical trends for its applications are introduced.
\end{abstract}

Key words : Li-M-O materials, Cathode, Solid electrolyte, Anode, Nuclear fusion materials

\section{Part 1. Li-M-O Materials for Lithium Secondary Batteries}

\section{Cathode Materials for Lithium Secondary Batteries}

C 1.1. Introduction

athode materials are significant, accounting for about $35 \%$ of the lithium secondary battery material cost; these materials are classified according to the crystal structure and the constituents of the metallic salt. Crystalline structures under consideration are divided into layered rock salt, spinel, and olivine type structures. In addition, $\mathrm{Co}, \mathrm{Ni}$, $\mathrm{Mn}, \mathrm{Al}, \mathrm{Fe}$, and others are studied mainly as constituents of metal salts. Fig. 1 shows the three main types of crystal structure under consideration as cathode materials for lithium secondary batteries.

The requirements for the cathode materials of the lithium secondary battery are as follows:

1. High Energy Density

2. High Life Cycle

3. Superb Charge/Discharge Rate

4. Affordable Price

5. Environmentally Friendly

$\mathrm{CoO}_{2}$, which has a layered rock salt type structure, is the most widely used cathode material for lithium secondary

${ }^{\dagger}$ Corresponding author: Young Soo Yoon

E-mail : benedicto@gachon.ac.kr

Tel : +82-31-750-8988 Fax : +82-31-750-8839 batteries, and is still the mainstay in the industry today. However, cobalt (Co), which is used in the production of $\mathrm{LiCoO}_{2}$, is a rare metal with a small amount of reserves; also, areas that can produce this material are limited. Therefore, it is disadvantageous in that the unit price is expensive and in that the material is unstable in terms of supply. For this reason, many studies have been carried out in the direction of not using cobalt or in minimizing its usage. As prime examples, there is $\mathrm{LiMn}_{2} \mathrm{O}_{4}$, which has a spinel type structure that uses $\mathrm{Mn}$, and the $\mathrm{LiNiO}_{2}$ layered rock salt structure, which uses $\mathrm{Ni}$. Both $\mathrm{Ni}$ and $\mathrm{Mn}$ are easily available compared to cobalt. In addition, research on ternary alloy materials using combinations of $\mathrm{Ni}$, Co, and $\mathrm{Mn}$, or $\mathrm{Ni}, \mathrm{Co}$, and $\mathrm{Al}$ have been actively conducted. ${ }^{2)}$ However, the structure of $\mathrm{LiNiO}_{2}$ is unstable in the charged state, and the performance of $\mathrm{LiMn}_{2} \mathrm{O}_{4}$ deteriorates at high temperature. For these reasons, the tritium alloys of $\mathrm{Li}[\mathrm{Ni}$, $\mathrm{Co}, \mathrm{Mn} \mathrm{O}_{2}$ are the most actively used materials in industry, and not $\mathrm{LiCoO}_{2}$. The general characteristics of the aforementioned materials are listed below in Table 1 .

\section{2. $\mathrm{LiCoO}_{2}$}

$\mathrm{LiCoO}_{2}$ has a layered rock salt structure called " $\alpha$ $\mathrm{NaFeO}_{2}$ ”, in which oxide ions constitute a (111) plane, and lithium ions and cobalt ions are alternately present between the layers. An attempt to apply such a layered oxide containing lithium ion as a cathode material was made when the Mizushima Corporation discovered in 1980 that $\mathrm{LiCoO}_{2}$ in a solution of $1 \mathrm{M} \mathrm{LiBF}_{4} / \mathrm{PC}$ exhibited a potential of $4 \mathrm{~V}$ to lithium metal and that reversible insertion and desorption of lithium ions was possible. ${ }^{3,4)}$ 
Table 1. Types and Characteristics of Cathode Materials for Lithium Secondary Batteries

\begin{tabular}{llllll}
\hline \multicolumn{1}{c}{ Material } & \multicolumn{1}{c}{$\mathrm{LiCoO}_{2}$} & \multicolumn{1}{c}{$\mathrm{LiNiO}_{2}$} & $\mathrm{LiMn}_{2} \mathrm{O}_{4}$ & $\mathrm{LiFePO}_{4}$ & $\mathrm{LiNi}_{1 / 3} \mathrm{Co}_{1 / 3} \mathrm{Mn}_{1 / 3} \mathrm{O}_{2}$ \\
\hline Crystal Structure & Layered & Layered & Spinel & Olivine & Layered \\
Operating Voltage & $3.7 \mathrm{~V}$ & $3.5 \mathrm{~V}$ & $4.0 \mathrm{~V}$ & $3.2 \mathrm{~V}$ & $3.6 \mathrm{~V}$ \\
Practical Capacity & $145 \mathrm{mAh} \mathrm{g}^{-1}$ & $175 \mathrm{mAh} \mathrm{g} \mathrm{V}^{-1}$ & $100 \mathrm{mAh} \mathrm{g} \mathrm{g}^{-1}$ & $150 \mathrm{mAh} \mathrm{g}^{-1}$ & $140 \mathrm{mAh} \mathrm{g}^{-1}$ \\
Stability & high & low & middle & very high & high \\
Cycle Performance & high & low & low & high & high \\
Cost & high & middle & middle & low & middle \\
\hline
\end{tabular}

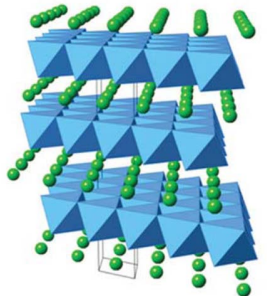

(a)

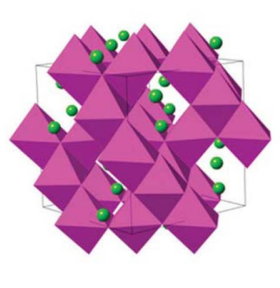

(b)

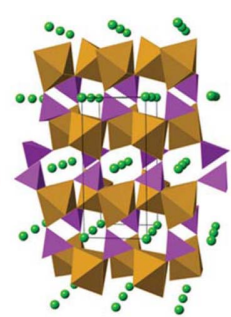

(c)
Fig. 1. Representative crystal structures of cathode materials for lithium secondary batteries: (a) layered $\mathrm{LiCoO}_{2}, \mathrm{LiNiO}_{2}, \mathrm{LiMn}_{\mathrm{x}} \mathrm{Co}_{\mathrm{y}} \mathrm{Mn}_{\mathrm{z}} \mathrm{O}_{2}$; (b) cubic $\mathrm{LiMn}_{2} \mathrm{O}_{4}$ spinel; (c) olivine structured $\mathrm{LiFePO}_{4}{ }^{1 \text { ) }}$

Insertion / desorption proceeds as lithium ions migrate into a two-dimensional plane with a $\mathrm{CoO}_{6}$ octahedral structure. Since lithium ions are intercalated/deintercalated in a state in which the crystal structure, composed of an oxide and a cobalt ion, is maintained, good characteristics are exhibited in a normal charge/discharge cycle. The fact that expansion/contraction only occurs during the charging/discharging cycle can be advantageous when the battery is built because the use of graphite as an anode leads to the opposite effect. In addition, since the diffusion path of lithium ions is a single layer of a two-dimensional plane, it is advantageous in terms of the characteristics of the battery, which has a larger diffusion coefficient than those of other crystal structures. From the manufacturability aspect, $\mathrm{LiCoO}_{2}$ also has a great advantage as a cathode material for a lithium secondary battery because a good quality product can be obtained by a relatively simple process.

Although, due to ly used as a cathode material for lithium secondary batteries in the early days, the continuous use of $\mathrm{LiCoO}_{2}$ has been greatly limited by the increase in unit price due to the scarcity of the source material. Fig. 2 shows charge/discharge curves at $\mathrm{C} / 24$ rate in the range of 3.6-4.85 $\mathrm{V}$. The curves show that $\mathrm{LiCoO}_{\mathrm{x}}$ has several phases during the range of electrochemical cycling. ${ }^{5)}$ In addition, there is a problem of phase change when this material is charged excessively during the charging / discharging process. That is, when the amount of lithium ions desorbed exceeds 0.5, the phase changes from hexagonal to monoclinic, and the structure of $\mathrm{LiCoO}_{2}$ becomes unstable. In order to prevent such a phenomenon, the charging voltage is limited to about $4.2 \mathrm{~V}$ when $\mathrm{LiCoO}_{2}$ is used as the cathode material of a lith-

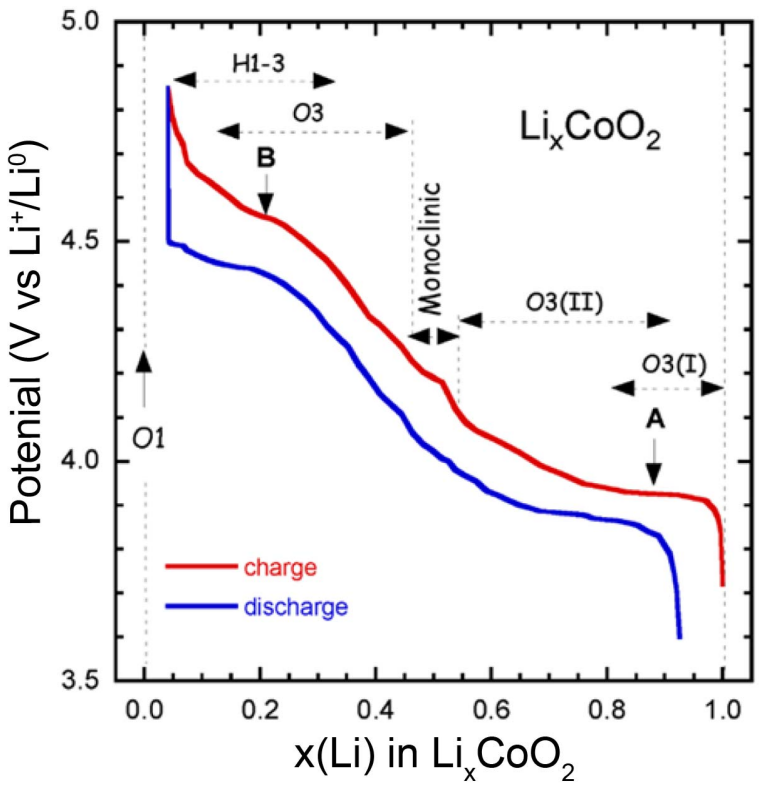

Fig. 2. Charge-discharge curves of $\mathrm{Li}_{\mathrm{x}} \mathrm{CoO}_{2}$ at $\mathrm{C} / 24$ rate in the range of $3.6-4.85 \mathrm{~V}$ vs. $\mathrm{Li}_{0} / \mathrm{Li}_{+}$. The sequence of the several phases is indicated as $\mathrm{x}$ varies from 1.0 $0.05 .5)$

ium secondary battery. For this reason, the theoretical capacity of $\mathrm{LiCoO}_{2}$ is $274 \mathrm{mAh} \mathrm{g}^{-1}$, but the capacity that can actually be used is limited to $130-150 \mathrm{mAh} \mathrm{g}^{-1}$.

The charge / discharge reaction is as follows:

$$
\mathrm{LiCoO}_{2} \underset{\text { Discharge }}{\stackrel{\text { Charge }}{\rightleftarrows}} \mathrm{Li}_{0.5} \mathrm{CoO}_{2}+0.5 \mathrm{Li}+0.5 \mathrm{e}^{-}
$$

Many studies are being conducted to develop a cathode material for a lithium secondary battery with excellent properties that can compensate for the shortcomings of $\mathrm{LiCoO}_{2}$. The research is divided into two major categories:

1. Developing a method that can compensate for the flaws of $\mathrm{LiCoO}_{2}$

2. Finding a new material that can replace $\mathrm{LiCoO}_{2}$

In order to compensate for the disadvantages of $\mathrm{LiCoO}_{2}$, many studies on surface coating using metal oxide were conducted. Studies on the surface coating of $\mathrm{LiCoO}_{2}$ using 

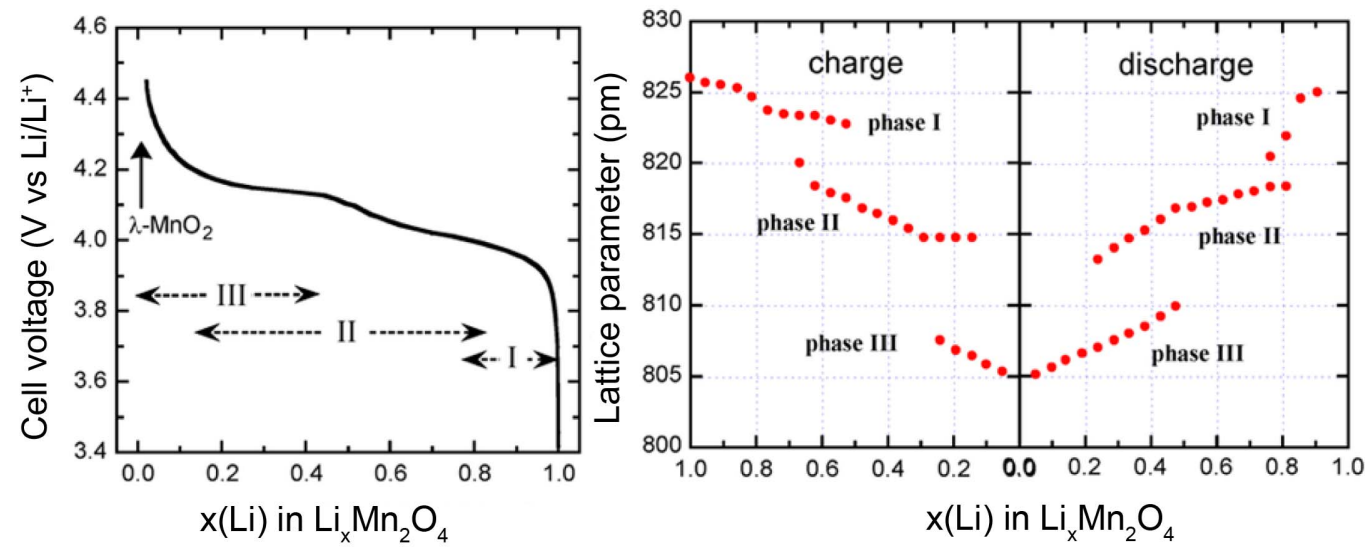

Fig. 3. Voltage profile of an $\mathrm{Li} / / \mathrm{LiMn}_{2} \mathrm{O}_{4}$ cell discharged at $\mathrm{C} / 24$ rate with $\mathrm{LMO}$ material synthesized at $700{ }^{\circ} \mathrm{C}$ (left).Variation of the lattice parameters as a function of the $\mathrm{Li}$ content $\mathrm{x}$ during charge/discharge in the LMO cathode (right). ${ }^{5)}$

$\mathrm{ZrO}_{2}, \mathrm{Al}_{2} \mathrm{O}_{3}, \mathrm{MgO}, \mathrm{SiO}$, etc., have been carried out and the life cycle of $\mathrm{LiCoO}_{2}$ during charging/discharging cycles at potentials of $4.2 \mathrm{~V}$ or higher has improved significantly compared to that of $\mathrm{LiCoO}_{2}$ without metal oxide. This improvement has been due to the suppression of physical phase change, inhibition of elution of cobalt ions, and suppression of increased interfacial resistance. ${ }^{6)}$

\section{3. $\mathrm{LiNiO}_{2}$}

$\mathrm{LiNiO}_{2}$, which has the same crystal structure $\left(\alpha-\mathrm{NaFeO}_{2}\right)$ as $\mathrm{LiCoO}_{2}$, has been studied for a long time as a replacement cathode material for $\mathrm{LiCoO}_{2}$. Because it has a crystal structure identical to that of $\mathrm{LiCoO}_{2}$, it exhibits characteristics equivalent to those of $\mathrm{LiCoO}_{2}$ in various aspects. In fact, $\mathrm{LiNiO}_{2}$ is 1.2 times larger than $\mathrm{LiCoO}_{2}$ in terms of capacity because the amount of lithium that can be extracted is 0.7 for $\mathrm{LiNiO}_{2}$, which is higher than the 0.5 extraction value for $\mathrm{LiCoO}_{2}$. Also, it is easier to supply nickel, due to its low cost, than it is to supply cobalt.

The price of nickel is also cheaper than cobalt, which is superior in terms of supply.

The charge / discharge reaction is as follows:

$$
\mathrm{LiNiO}_{2} \underset{\text { Discharge }}{\stackrel{\text { Charge }}{\underset{2}{\rightleftarrows}}} \mathrm{Li}_{0.3} \mathrm{Ni}{ }_{\ni} \mathrm{O}_{2}+0.7 \mathrm{Li}+0.7 \mathrm{e}^{-}
$$

However, $\mathrm{LiNiO}_{2}$ has some problems when materials are synthesized. In order for $\mathrm{LiNiO}_{2}$ to be activated electrochemically, it must stay as $\mathrm{Ni}^{3+}$ for the lithium to exist, but it is easy for $\mathrm{Ni}^{3+}$ to be reduced to $\mathrm{Ni}^{2+}$ during material synthesis. If $\mathrm{Ni}^{2+}$ is present instead of $\mathrm{Ni}^{3+}$, it is easy for lithium to become $\mathrm{Li}_{1-\mathrm{x}} \mathrm{Ni}_{1+\mathrm{x}} \mathrm{O}_{2}$. This phenomenon leads to the diffusion of lithium ions and to a deterioration in the cycle of charge and discharge. Many synthetic methods have been studied as alternatives, but there is no clear solution yet. Also, when $\mathrm{Li}$ is removed from $\mathrm{LiNiO}_{2}$, the $\mathrm{Ni}$ moves to the position of $\mathrm{Li}$. When the number of $\mathrm{Li}$ is large, $\mathrm{Li}$ occupies the location of $\mathrm{Ni}$; this deteriorates the charge and discharge rate. Such inversion of $\mathrm{Li}$ and $\mathrm{Ni}$, and the low thermal stability, prevent $\mathrm{LiNiO}_{2}$ from being commercialized.

\section{4. $\mathrm{LiMn}_{2} \mathrm{O}_{4}$}

The spinel structure generally has the form of $\mathrm{AB}_{2} \mathrm{X}_{4}$. $\mathrm{LiMn}_{2} \mathrm{O}_{4}$ generally has this spinel structure and $\mathrm{Mn}$ ion occupies the $16 \mathrm{~d}$ octahedral site, while Li ion occupies the 8 a tetrahedral site. The $16 \mathrm{c}$ octahedral site, which is near the $8 \mathrm{a}$ tetrahedral site (occupied by $\mathrm{Li}$ ion), is empty; this path is necessary for $\mathrm{Li}$ ion to diffuse inside $\mathrm{LiMn}_{2} \mathrm{O}_{4}$. Fig. 3 provides the voltage profile of an $\mathrm{Li} / / \mathrm{LiMn}_{2} \mathrm{O}_{4}$ cell discharged at $\mathrm{C} / 24$ rate with LMO material synthesized at $700^{\circ} \mathrm{C}$.) During the process of charging and discharging, a flat section appears in the region of $3 \mathrm{~V}$ and $4 \mathrm{~V}$. However, in the $3 \mathrm{~V}$ region, $\mathrm{Li}$ ions are further inserted into the $16 \mathrm{c}$ site; this generates $\mathrm{Li}_{2} \mathrm{Mn}_{2} \mathrm{O}_{4}$, which results in degradation in the cycles due to volumetric expansion. ${ }^{7)}$

Compared to other cathode materials, $\mathrm{LiMn}_{2} \mathrm{O}_{4}$ has a small capacity. It also has problems during charge and discharge cycles in the $4 \mathrm{~V}$ region. The leading causes for these problems include dissolution of $\mathrm{Mn}$ in the organic electrolytes, ${ }^{8,9)}$ structural instability, ${ }^{10,11)}$ and the Jahn-Teller Effect. ${ }^{12)}$ For these reasons, studies are underway to improve the cycle of charging and discharging by replacing a part of the Mn with another metal.

The charge / discharge reaction is as follows:

$$
\mathrm{LiMnO}_{2} \underset{\text { Discharge }}{\stackrel{\text { Charge }}{\rightleftarrows}} \mathrm{Li}_{0.3} \mathrm{Mn}_{2} \mathrm{O}_{4}+0.7 \mathrm{Li}+0.7 \mathrm{e}^{-}
$$

\section{5. $\mathrm{LiFePO}_{4}$}

$\mathrm{LiFePO}_{4}$, an olivine-type compound, is an excellent cathode material due to its high capacity and the low cost of its raw material. In particular, due to its excellent cycle of charging / discharging, and its thermal stability, it is attracting attention from many researchers in the industry 
as a cathode material for batteries of large-sized electric vehicles. $\mathrm{LiFePO}_{4}$ has been studied continuously since the Goodenough Corp. used a polyanion in the form of $\mathrm{XO}_{4}^{\mathrm{y}-}(\mathrm{X}=$ $\mathrm{S}, \mathrm{P}, \mathrm{As}, \mathrm{Mo}, \mathrm{W}, \mathrm{y}=2,3)$ to develop an Fe compound with an operating voltage of $3.4 \mathrm{~V}^{13,14)} \mathrm{LiFePO}_{4}$ is a cheap material with outstanding life cycle and thermal stability; it is also environmentally friendly. Despite these advantages, the use of this material is still limited. This is because this material is difficult to charge and discharge rapidly due to its low electrical conductivity $\left(10^{-10} \mathrm{~S} \mathrm{~cm}^{-1}\right)$. In order to solve these problems, two approaches are under study. The first is to increase the surface area of the sample that will be used in the reaction by inserting particles with large specific surface area into the nanostructure. The second method is to coat a conductive material such as carbon onto the surface of the particles. A variety of studies have been conducted using these two methods, and a lot of progress has been made until now. ${ }^{15-19)}$

The charge / discharge reaction is as follows:

$$
\mathrm{LiFePO}_{4} \underset{\text { Discharge }}{\stackrel{\text { Charge }}{\rightleftarrows}} \mathrm{Li}_{1-x} \mathrm{FePO}_{4}+x \mathrm{Li}^{+}+x \mathrm{e}^{-}
$$

\section{6. $\mathrm{LiNi}_{x} \mathrm{Co}_{y} \mathrm{Mn}_{z} \mathrm{O}_{2}$}

$\mathrm{LiNi}_{\mathrm{x}} \mathrm{Co}_{\mathrm{y}} \mathrm{Mn}_{\mathrm{z}} \mathrm{O}_{2}$ is a ternary cathode material with a crystal structure identical to that of $\mathrm{LiCoO}_{2}$; its capacity and operating voltage are similar to those of $\mathrm{LiCoO}_{2}$. According to the research, it is possible to charge and discharge this material with a high capacity of $200 \mathrm{mAh} \mathrm{g}^{-1}$ when the voltage is raised to $4.6 \mathrm{~V}^{20)} \mathrm{LiNi}_{\mathrm{x}} \mathrm{Co}_{\mathrm{y}} \mathrm{Mn}_{\mathrm{z}} \mathrm{O}_{2}$ has a high thermal stability compared to that of $\mathrm{LiNiO}_{2}$, and it uses a 3 times lower amount of $\mathrm{Co}$ compared to $\mathrm{LiCoO}_{2}$. Many studies have been done on the possibility that a solid solution compound of the transition metal can be used to take advantage of existing materials and mitigate the mentioned disadvantages. Among potential materials, $\mathrm{LiNi}_{\mathrm{x}} \mathrm{Co}_{\mathrm{y}} \mathrm{Mn}_{\mathrm{z}} \mathrm{O}_{2}$ is one of the few solid solution compounds that is actually being used in the industry, and it is the closest to becoming commercialized.

\section{Solid Electrolyte Materials for Lithium Secondary Batteries}

\subsection{Introduction}

Secondary batteries provide high energy for various electronic devices, but they are subject to flame hazard because they use volatile and highly reactive liquid electrolytes. Next generation secondary batteries will use solid electrolytes instead of liquid electrolytes, and research is underway to fabricate batteries with low flame hazard. ${ }^{21,22)}$ Advantages of batteries manufactured using solid electrolytes (also known as "all solid-state batteries") are that they do not use liquid electrolytes, so there is little risk of fire, and that there is no leakage of liquid. In addition, such batteries are safe for use at high temperature and pressure, and their low self-discharge rate enables long-term storage. Unlike liquid electrolytes, solid electrolytes do not leak, so there is no restriction on packing, and this means the battery can be miniaturized. In order to manufacture all solidstate batteries with these advantages, it is important to develop a new solid electrolyte with excellent electrolyte performance. The performance of the battery is affected by the internal movement of $\mathrm{Li}$ ions. Therefore, the higher the ionic conductivity of the solid electrolyte is, the better the performance of the battery is. ${ }^{23-25)}$

The following are additional requirements for solid-state batteries:

1. Interfacial stability between anode and cathode

2. High chemical structural stability

3. Large working windows of voltage and current

4. Stability over a wide temperature range

5. Low corrosion and high thermal mechanical strength (for demanding environments)

6. Economically and environmentally friendly

The solid electrolytes that are being studied recently are LiSiCON, NASiCON, the Garnet type, the Perovskite type, the anti-perovskite type, and more. A lot of the research that has been conducted has mainly focused on the wide range of chemical compositions and crystal structures. Fig. 4 shows serval types of solid electrolytes with good ion conductivity for use in lithium secondary batteries.

In order to understand Li-M-O solid electrolytes, this chapter mainly focuses on their structure and material properties. Also, this chapter will discuss the pros and cons of these electrolytes, and how we will overcome their flaws.

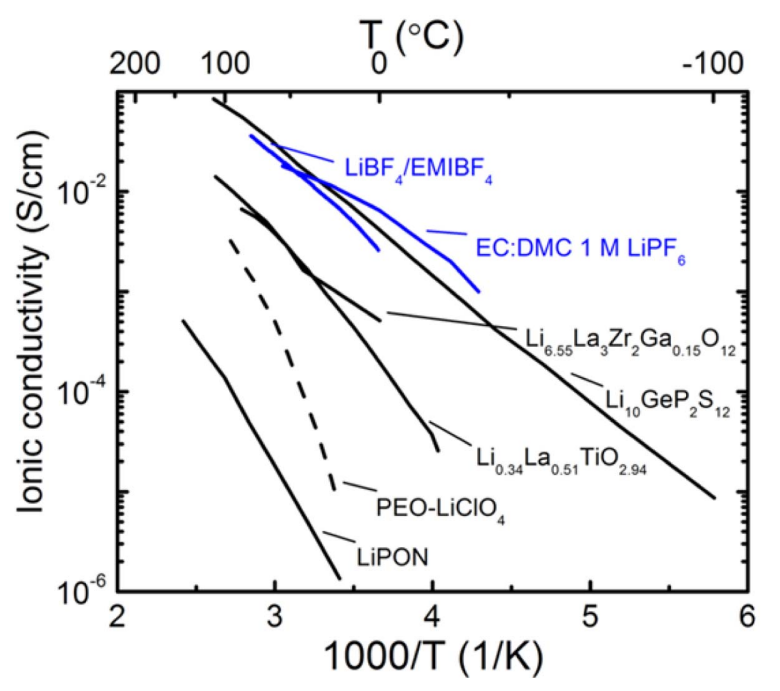

Fig. 4. Reported total lithium ion conductivity as function of temperature. ${ }^{26)}$ 


\subsection{NASICON type solid electrolyte}

The general structure of the NASICON (Na super ionic conductor) solid electrolyte is expressed as $\mathrm{AM}_{1} \mathrm{M}_{2} \mathrm{P}_{3} \mathrm{O}_{12}$ / $\mathrm{AM}_{1} \mathrm{M}_{2}\left(\mathrm{PO}_{4}\right)_{3}$. One $\mathrm{AO}_{6}$ octahedron and the $\mathrm{PO}_{4}$ tetrahedrons share six oxygen atoms at the edges to form a three dimensional skeleton. Three-dimensional channels $\left(M_{1}, M_{1 / 2}\right.$, $\mathrm{M}_{2}$ ) are formed in the crystal lattice and the conduction of ions become possible. B-alumina, $\mathrm{Na}_{3} \mathrm{Zr}_{2} \mathrm{Si}_{2} \mathrm{PO}_{12}$, and $\mathrm{NaZr}_{2}$ $\left(\mathrm{PO}_{4}\right)_{3}$ are materials representative of the NASICON structure (Fig. 5). ${ }^{28)}$ Many studies have been conducted on $\mathrm{Li}_{1+\mathrm{x}} \mathrm{Al}_{\mathrm{x}} \mathrm{Ti}_{2-\mathrm{x}}\left(\mathrm{PO}_{4}\right)_{3}$ (LATP) $(0 \leq \mathrm{x} \leq 0.4, \mathrm{LATP})$, in which $\mathrm{Na}$ and $\mathrm{Zn}$ are replaced by $\mathrm{Li}$ and $\mathrm{Ti}$ ions and some $\mathrm{Al}^{29)} \mathrm{NaZr}_{2}$ $\left(\mathrm{PO}_{4}\right)_{3}$ shows a low ionic conductivity of about $10^{-5} \mathrm{~S} \mathrm{~cm}^{-1}$ at $300{ }^{\circ} \mathrm{C}$, but it has been reported that this ionic conductivity increases tenfold when $\mathrm{Na}$ is replaced with $\mathrm{Li}^{30)}$ When $\mathrm{Zr}^{4+}$ ions are replaced by $\mathrm{Ti}^{4+}$ ions, which are small in size, the ionic conductivity improves due to the formation of a channel that is more suitable for ions to move in, while the skeletal structure of NASICON is maintained. Many studies have been conducted on $\mathrm{Li}_{1+\mathrm{x}} \mathrm{Al}_{\mathrm{x}} \mathrm{Ti}_{2-\mathrm{x}}\left(\mathrm{PO}_{4}\right)_{3}$ (LATP) $(0 \leq \mathrm{x} \leq$ 0.4 , LATP), in which $\mathrm{Na}$ and $\mathrm{Zn}$ are replaced by $\mathrm{Li}$ and $\mathrm{Ti}$ ions and some $\mathrm{Al}^{31,32)}$ The structure of LATP depends on the amount of lithium inserted; the ionic conductivity of $\mathrm{Li}_{1.3} \mathrm{Ti}_{1.7} \mathrm{Al}_{0.3}\left(\mathrm{PO}_{4}\right)_{3}$ was at its highest $\left(10^{-2}-10^{-3} \mathrm{~S} \mathrm{~cm}^{-1}\right)$ when the $\mathrm{x}$ value was 0.3 . Research on the synthesis of LATP is continuously being performed using various methods such as solid state reaction, sol-gel reaction, hydrothermal reaction, and more. Studies have reported that the ionic conductivity increased with the replacement of $\mathrm{Ti}^{4+}$ and $\mathrm{P}^{5+}$ ions with trivalent cations (Al, Ga, Sc, In, Y) in the LATP structure. ${ }^{33,34)}$ However, when LATP comes in contact with $\mathrm{Li}$ metal, which is used as a cathode, $\mathrm{Ti}^{4+}$ is reduced to $\mathrm{Ti}^{3+}$ and it becomes difficult to apply these methods to all solid-state batteries. LAGP substitutes $\mathrm{Ge}^{4+}$ for $\mathrm{Ti}^{4+}$; therefore, LAGP is attracting more attention than LATP as a solid electrolyte because LAGP makes $\mathrm{Li}$ more stable by replacing $\mathrm{Ti}^{4+}$ with $\left.\mathrm{Ge}^{4+} \cdot 35\right)$

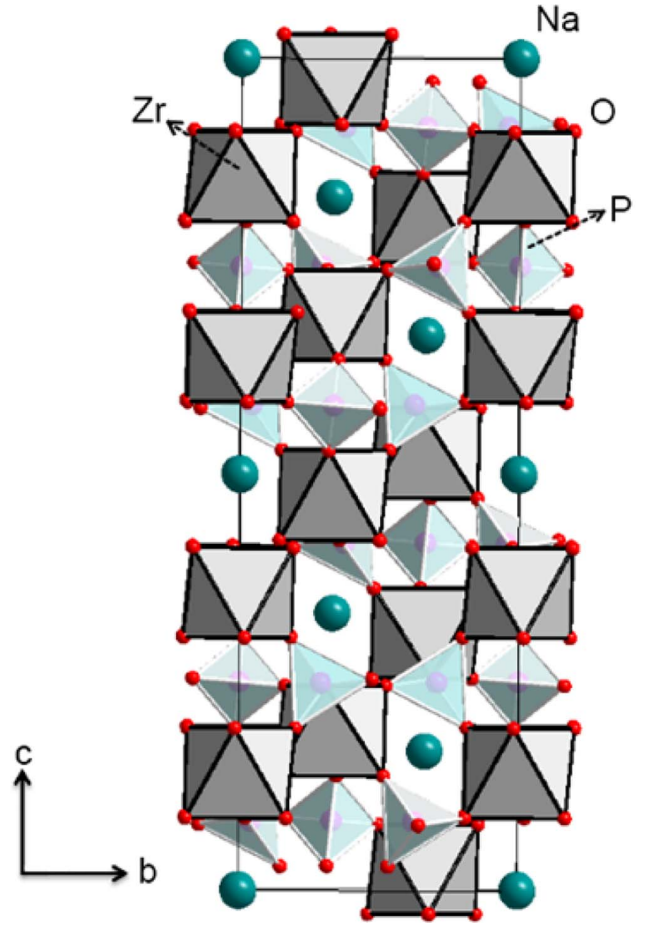

Fig. 5. Crystal structure of $\mathrm{NaZr}_{2}\left(\mathrm{PO}_{4}\right)_{3}$. The solid box indicates the unit cell. ${ }^{27}$

\subsection{Garnet type solid electrolyte}

The general structure of a garnet type solid electrolyte is expressed as $\mathrm{A}_{3} \mathrm{~B}_{3} \mathrm{C}_{2} \mathrm{O}_{12}$, which forms as a tetrahedron (site $\mathrm{A}$ ), a dodecahedron (site $\mathrm{B}$ ), and an octahedron (site C), and coordinating oxygen atoms. ${ }^{36,37)}$ Fig. 6 shows the crystal structure of $\mathrm{Li}_{5} \mathrm{La}_{3} \mathrm{M}_{2} \mathrm{O}_{12}(\mathrm{M}=\mathrm{Nb} / \mathrm{Ta})$. Among the garnet type solid electrolytes, Lithium Lanthanum Zirconia Oxide (LLZO), which was studied by Weppner's group in 2007, has been the most studied compound. LLZO has cubic and tetragonal structures, with ionic conductivity values of $\sim 5 \mathrm{x}$ $10^{-4} \mathrm{~S} \mathrm{~cm}^{-1}$ in the cubic structure and $1.6 \times 10^{-6} \mathrm{~S} \mathrm{~cm}^{-1}$ in the

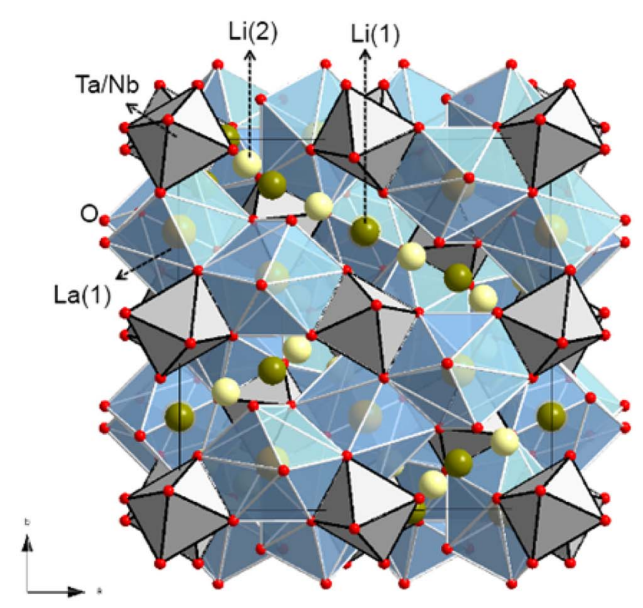

(a)

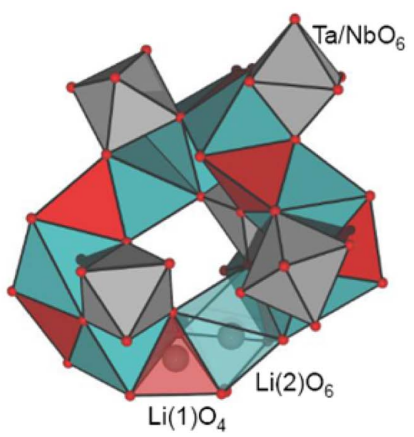

(b)

Fig. 6. Crystal structure of $\mathrm{Li}_{5} \mathrm{La}_{3} \mathrm{M}_{2} \mathrm{O}_{12}(\mathrm{M}=\mathrm{Nb} / \mathrm{Ta})$ (a). Details of $3 \mathrm{D}$ lithium ion migration pathway in $\mathrm{Li}_{5} \mathrm{La}_{3} \mathrm{M}_{2} \mathrm{O}_{12}\left(\mathrm{M}=\mathrm{Nb} / \mathrm{T}\right.$ a) $(b)$. $\left.{ }^{27}\right)$ 

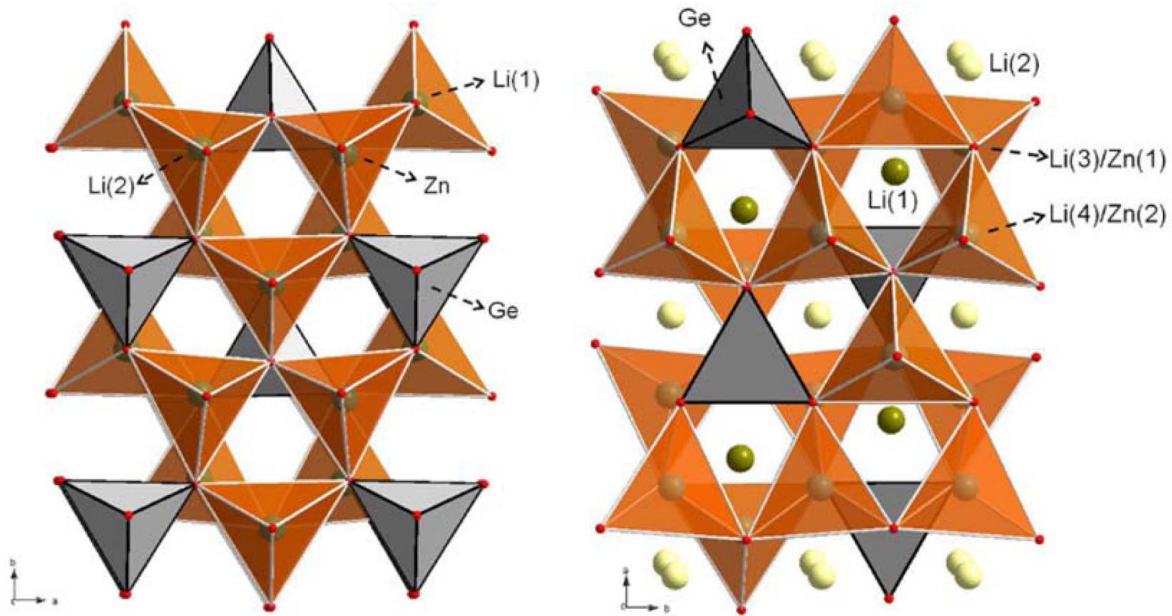

Fig. 7. Crystal structures of $\mathrm{Li}_{2} \mathrm{ZnGeO}_{4}$ (a) and $\mathrm{Li}_{3.5} \mathrm{Zn}_{0.25} \mathrm{GeO}$ sites within the rigid network of LISICON.

tetragonal structure. ${ }^{38,39)}$ In previous research, a method of synthesizing LLZO by adding $\mathrm{Al}^{+}$to form a stable cubic structure has been studied. ${ }^{40,41)}$ Ever since then, many synthesis studies were performed by adding a variety of cations. ${ }^{40,42)}$ Other garnet compound includes lithium lanthanum metal oxide $($ Metal $=\mathrm{Nb}, \mathrm{Ta}) ; \mathrm{Li}_{6} \mathrm{ALa}_{2} \mathrm{M}_{2} \mathrm{O}_{12}$ with $\mathrm{Ca}, \mathrm{Sr}$, and $\mathrm{Ba}$ (position $\mathrm{A}$ ) has ionic conductivity of $4 \times 10^{-5} \mathrm{~S} \mathrm{~cm}^{-1}{ }^{43}$ ) In order to synthesize a solid electrolyte with a garnet structure, the material must be made to remain at a high temperature of $1100^{\circ} \mathrm{C}$ for a long period. During this process, $\mathrm{Li}^{+}$ ions become volatile and either the garnet structure collapses or a solid electrolyte with low ionic conductivity is synthesized. Experiments are underway to synthesize solid electrolytes with excellent properties.

\subsection{LISICON-type solid electrolyte}

LISICON, which was introduced by Bruce and West, is an abbreviation of "Lithium Super Ionic Conductor"; its structural formula is $\mathrm{Li}_{2+2 \mathrm{x}} \mathrm{Zn}_{1-\mathrm{x}} \mathrm{GeO}_{4}{ }^{44)}$ Due to its structure, lithium ions are distributed between two different octahedron sites $\left(\mathrm{Li}_{1}\right.$ and $\mathrm{Li}_{2}$ sites inside the lattice) and move between them. $\mathrm{Li}_{3.5} \mathrm{Zn}_{0.25} \mathrm{GeO}_{4}$ has a high ionic conductivity of $1.2 \times$ $10^{-1} \mathrm{~S} \mathrm{~cm}^{-1}$ at $300^{\circ} \mathrm{C}$, but a low ionic conductivity of $10^{-7} \mathrm{~S}$ $\mathrm{cm}^{-1}$ at room temperature. ${ }^{45)}$ The Li-rich $\mathrm{Li}_{3.5} \mathrm{Zn}_{0.25} \mathrm{GeO}_{4}$ structure octahedron sites are shown in Fig. 7. The use of $\mathrm{Li}_{3.5} \mathrm{Zn}_{0.25} \mathrm{GeO}_{4}$ for batteries is limited at room temperature. On the other hand, thio-LISICON (e.g. $\mathrm{Li}_{4} \mathrm{GeS}_{4}, \mathrm{Li}_{3} \mathrm{PS}_{4}$, $\mathrm{Li}_{5} \mathrm{AlS}_{4}$ ), in which oxygen is replaced by sulfur, has an ion conductivity value that is 100 times higher than that of oxide type LISICON. ${ }^{46,47)}$ In particular, $\mathrm{Li}_{3.25} \mathrm{Ge}_{0.25} \mathrm{P}_{0.75} \mathrm{~S}_{4}$ has a high ionic conductivity of $2.2 \times 10^{-3} \mathrm{~S} \mathrm{~cm}^{-1}$ at room temperature. Therefore, in the case of LISICON-type solid electrolytes, researchers are developing methods to replace the oxygen in thio-LISICON with sulfur.

\subsection{Perovskite type solid electrolyte}

Perovskite is also known to have a formula of $\mathrm{ABO}_{3}$; the

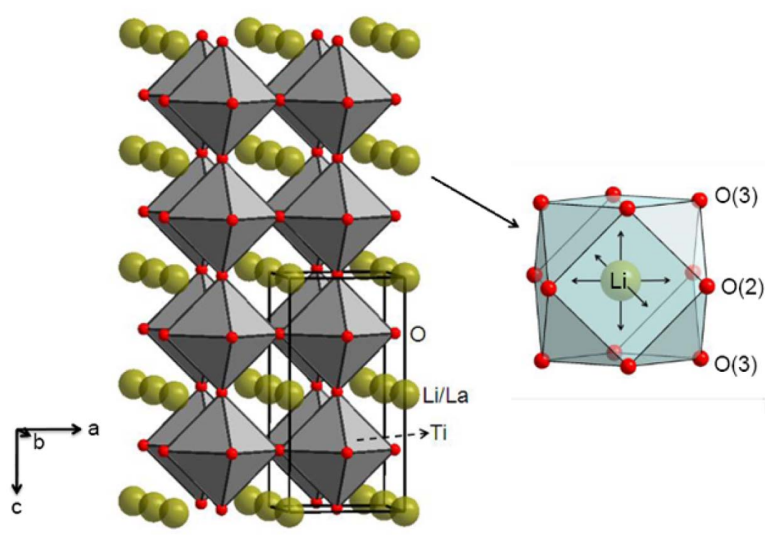

(a)

(b)

Fig. 8. Crystal structure of tetragonal $\mathrm{Li}_{3 \mathrm{x}} \mathrm{La}_{3 / 2-\mathrm{x}} \mathrm{TiO}_{3}$ (a). Lithium, lanthanum, and vacancies are distributed at the A-sites. Schematic representation of 3D mobility of lithium ions in the perovskite structure (b). ${ }^{27}$

$\mathrm{BO}_{3}$ surrounding the A-site ions becomes the frame of the crystal structure. ${ }^{48,49)}$ The perovskite structure (ex. tetragonal $\mathrm{Li}_{3 \mathrm{x}} \mathrm{La}_{3 / 2-\mathrm{x}} \mathrm{TiO}_{3}$ ) is shown in Fig. 8. The first research into the Li-M-O type perovskite material was conducted after a study on the A-site deficiency structure was undertaken by Latie and Belous; in this study, $\mathrm{La}_{2 / 3} \mathrm{TiO}_{3}$ was replaced with $\mathrm{Li}^{+}$instead of replacing it with $\mathrm{La}^{3+50,51)}$ After that study, a variety of materials have been studied. As of now, the most widely studied material is $\mathrm{Li}_{0.34} \mathrm{La}_{0.51} \mathrm{TiO}_{2.94}$ (LLTO); its ionic conductivity is $2 \times 10^{-5} \mathrm{~S} \mathrm{~cm}^{-1}$, which is relatively high compared to the values of other materials. ${ }^{52)}$ LLTO has high ionic conductivity because its structure deforms when there are not a sufficient number of A-site ions. However, the ionic conductivity of LLTO differs between its total ion conductivity $\left(2 \times 10^{-5} \mathrm{~S} \mathrm{~cm}^{-1}\right)$ and bulk ion conductivity $\left(1 \times 10^{-3} \mathrm{~S} \mathrm{~cm}^{-1}\right)$. This shows that the movement of $\mathrm{Li}^{+}$ions is restricted by contact resistance generated at the grain boundaries. ${ }^{53)}$ In 
order to solve this issue, many studies have examined the effect of the heat treatment temperature in order to determine an optimum temperature. It was also necessary to reduce the activation energy and, for that reason, a variety of ions were studied as substitutions $\left(\mathrm{La}^{3+}=\mathrm{Pr}, \mathrm{Nb}, \mathrm{Sm}\right){ }^{54}$ )

LLTO has excellent ionic conductivity, but the intercalation of lithium causes $\mathrm{Ti}^{4+}$ to be substituted with $\mathrm{Ti}^{3+}$, resulting in a deterioration in the performance, which limits the use of this material as a solid electrolyte. Various studies have been carried out to improve the ionic conductivity of perovskite structure materials. For example, Martin et al. obtained an ion conductivity of $4.3 \times 10^{-5} \mathrm{~S} \mathrm{~cm}^{-1}$ by replacing $\mathrm{TiO}_{3}$ with $\mathrm{NbO}_{3}{ }^{49}$ )

\subsection{Anti-perovskite type solid electrolyte}

The anti-perovskite structure is a typical $\mathrm{ABO}_{3}$ perovskite structure, in which $\mathrm{A}$ is a monovalent metal cation, $\mathrm{B}$ is a divalent metal cation, and $\mathrm{O}$ is a negative monovalent anion. This structure is created when an anion element in the conventional perovskite structure is replaced with a cation metal. Zhao et al. were the first to study $\mathrm{Li}_{3} \mathrm{OA}(\mathrm{A}=$ halogen) anti-perovskites. ${ }^{23,24,55,56)}$ The most basic material of this structure is $\mathrm{Li}_{3} \mathrm{OCl}$, which has a high ionic conductivity $\left(0.85 \times 10^{-3} \mathrm{~S} \mathrm{~cm}^{-1}\right)$ and low activation energy. Fig. 9 shows the structure of $\mathrm{Li}_{3} \mathrm{ClO}$. This material has a structure of $\mathrm{Li}^{+}$ ion at the octahedral corner, $\mathrm{O}_{2}$ anion at the center, and $\mathrm{Cl}^{-}$ at the center of the $\mathrm{Li}_{6} \mathrm{O}$ octahedron. Recently, in Braga et al., a material with a glass-liquid transition of $\mathrm{Li}_{3-2 \mathrm{x}} \mathrm{M}_{\mathrm{x}} \mathrm{AO}$ $\left(\mathrm{M}=\mathrm{Mg}^{2+}, \mathrm{Ca}^{2+}, \mathrm{Ba}^{2+}, \mathrm{A}=\right.$ halogen) was synthesized in order to increase the ionic conductivity and obtain a high ionic conductivity of $2.5 \times 10^{-2} \mathrm{~S} \mathrm{~cm}^{-1}$. ${ }^{57)}$ However, despite the good performance of this anti-perovskite, it is necessary to study the mechanism of ion conduction up to date. In addition, studies conducted so far have mainly focused on the stability of the phase. Further, studies on defects and movements of ions in $\mathrm{Li}_{3} \mathrm{OCl}$ have been carried out through simulation. $^{56)}$ It is necessary to study the applicability of antiperovskite materials as solid electrolytes using various types of experiments and by subjecting results to verification.

\section{Anode Materials for Lithium Secondary Batteries}

\subsection{Introduction}

A battery's energy density increases as the charging voltage of the cathode increases (e.g. $4.1 \mathrm{~V} \rightarrow 4.3 \mathrm{~V}$ ), as the result the performance of the anode improves. When amorphous carbon was replaced with graphite, the voltage flatness improved and the anode capacity increased from 260 $\mathrm{mA} \mathrm{h} \mathrm{g}^{-1}$ to $360 \mathrm{~mA} \mathrm{~h} \mathrm{~g}^{-1}$. This value $\left(360 \mathrm{~mA} \mathrm{~h} \mathrm{~g}^{-1}\right)$ is very close to the theoretical capacity of graphite $\left(\mathrm{C}_{6} \mathrm{Li}\right)$ of $372 \mathrm{~mA}$ $\mathrm{h} \mathrm{g}^{-1}$. However, it is still necessary to improve the performance of this anode active material. In order to improve the performance of lithium ion secondary batteries, the following tasks must be accomplished:

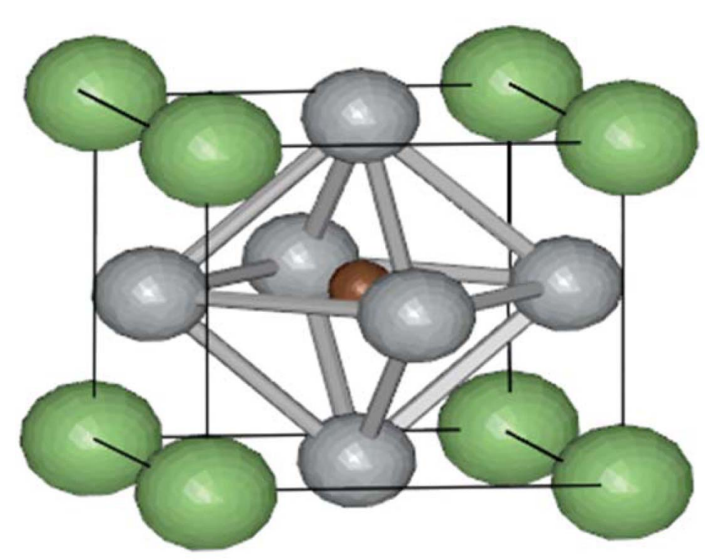

Fig. 9. Unit cell of cubic anti-perovskite. ${ }^{58)}$

1. The anode material must be replaced.

2. Electrode coating technology must be improved.

3. Electrode packing technology needs to be improved.

4. The $\mathrm{Li}$ ion absorption rate of the anode must be higher.

The ideas in three $(2 \sim 4)$ of the four statements listed above have reached their limit through space optimization within cell design and packaging. Therefore, it is necessary to increase the capacity of the anodic active material by developing a new an anode material and changing the structure itself.

The most noteworthy candidates for replacement of anode materials in the research so far are the following, including metal (M: Si, Sn, Sb, Al), M-O (M: Sn, Fe, Co, Ti, Ni), Li-M$\mathrm{O}$ (M: Sn, Ti, V), $\mathrm{Li}_{\mathrm{x}} \mathrm{M}_{\mathrm{y}} \mathrm{N}_{2}$ (M: Co). ${ }^{59-61)}$ These materials have higher capacity than that of commercialized graphite. Compared to graphite, which is a commercial cathode material, high-capacity metal-based materials go through rapid volume expansion during the alloying/dealloying process with $\mathrm{Li}$ ions. For example, Si has a theoretical capacity $\left(4,010 \mathrm{~mA} \mathrm{~h} \mathrm{~g}^{-1}\right)$ that is 10 or more times higher than that of the theoretical capacity of graphite $\left(372 \mathrm{~mA} \mathrm{~h} \mathrm{~g}^{-1}\right)$. However, the volume of Si increases by $300 \sim 400 \%$ (theoretically), while the volume of graphite only increases by $12 \%$. The following phenomenon also occurs in MO type anodic active materials; it is a problem that must be solved before it will be possible to replace graphite. On the other hand, $\mathrm{Li}_{4} \mathrm{Ti}_{5} \mathrm{O}_{12}$ (titanium based $\mathrm{Li}$ oxide) only goes through a slight change in crystal lattice of about 0.1 to $0.2 \%$ during the reaction with $\mathrm{Li}$ ions; it also has excellent power and high cycle life, and is safe. However, the disadvantage of Si is that its capacity is low because its reaction potential is high (higher than that of commercialized graphite).

\section{2. $\mathrm{Li}-\mathrm{Ti}-\mathrm{O}$ (LTO)}

$\mathrm{Li}_{4} \mathrm{Ti}_{5} \mathrm{O}_{12}$ (LTO), which has a cubic spinel structure, has been intensively studied by a number of researchers over the last 20 years. The performance of LTO has been improved through approaches such as changing the size (micro and nano) of the crystalline particles, changing the 
shapes, creating different composites with other cathode materials, and carbon coating. LTO, which has a spinel structure (a type of crystal structure), has high electrochemical output due to its three-dimensional diffusion of $\mathrm{Li}$ ions. Jung et al. prepared carbon coated LTO anodes with high electrochemical performance. Because of its spherical shape and good electronic conductivity, a C coated LTO (5.2 wt \%) exhibited outstanding cyclability up to 100 cycles under 1,5 , and $10 \mathrm{C}$-rates with voltage windows in the range of $1-3 \mathrm{~V}$ (Li vs. $\mathrm{Li}^{+}$), as shown in Fig. 10. ${ }^{62)}$

The advantage of LTO is that it does not form an SEI (Solid-Electrolyte Interphase) because it reacts at a relatively high reaction potential $(\sim 1.5 \mathrm{~V}){ }^{63)} \mathrm{LTO}$, because it is thermally stable during the charging/discharging process, is receiving a lot of attention from researchers as an anode material for high output medium- to large- sized batteries. It is thermally stable because there is no exothermic reaction while the SEI on the electrode surface is being decomposed. However, the low energy density that results from the high reaction voltage, and the high cost, make it difficult to commercialize this material. ${ }^{64)}$
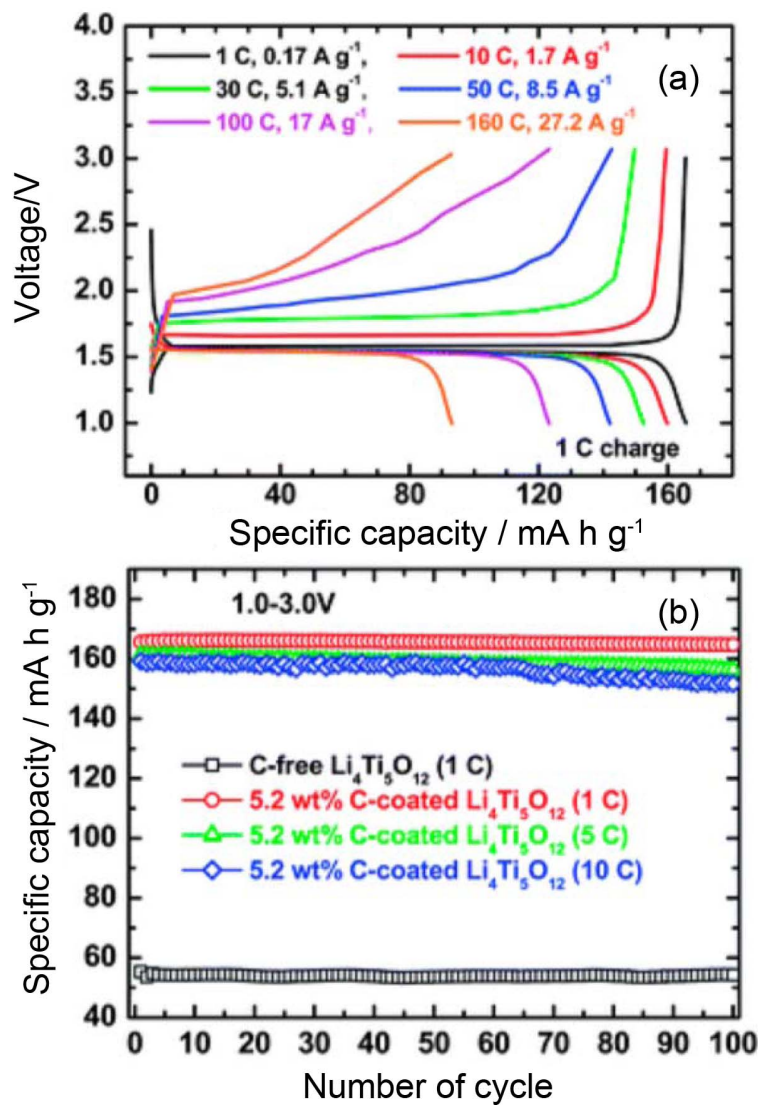

Fig. 10. (a) Rate capacity ability of $5.2 \mathrm{wt} \% \mathrm{C}$-coated $\mathrm{Li}_{4}$. $\mathrm{Ti}_{5} \mathrm{O}_{12}$ and (b) cycle performances of $5.2 \mathrm{wt} \% \mathrm{C}$ coated $\mathrm{Li}_{4} \mathrm{Ti}_{5} \mathrm{O}_{12}$ from $1 \mathrm{C}$ rate $\left(0.17 \mathrm{~A} \mathrm{~g}^{-1}\right)$ to $10 \mathrm{C}$ rate $\left(1.7 \mathrm{~A} \mathrm{~g}^{-1}\right)$ compared with performance of carbon free $\mathrm{Li}_{4} \mathrm{Ti}_{5} \mathrm{O}_{12}$ at $1 \mathrm{C}$ rate $\left(0.15 \mathrm{~A} \mathrm{~g}^{-1}\right)$ between 1.0 and $3 \mathrm{~V}\left(\mathrm{Li}\right.$ vs. $\left.\mathrm{Li}^{+}\right){ }^{62)}$

\section{3. $\mathrm{Li}-\mathrm{Co}-\mathrm{N}$}

NTT and Panasonic discovered $\mathrm{Li}_{2.6} \mathrm{Co}_{0.4} \mathrm{~N}$ is a nitride anode synthesized using a general ceramic method. A full cell test was carried out with various cathode materials having a high capacity of $900 \mathrm{~mA} \mathrm{~h} \mathrm{~g}^{-1}$ as well as low reaction potentials ranging from 0.1 to $1.4 \mathrm{~V}^{65)}$ However, this material has limitations for use as a commercial cathode material due to its low life cycle.

\section{4. $\mathrm{Li}-\mathrm{V}-\mathrm{O}$}

Vanadium-based Oxide $\left(\mathrm{Li}_{1.1} \mathrm{~V}_{0.9} \mathrm{O}_{2}\right)$ is an anodic active material that has a theoretical volume energy density of $\sim 1000 \mathrm{~mA} \mathrm{~h} \mathrm{cc}^{-1}$; this is because it reacts with $\mathrm{Li}$ ion at a low potential of $0.3 \mathrm{~V}$. For this reason, it is expected to be applicable to batteries with high energy density. However, in order to commercialize this material, it will be necessary to develop a way to increase the low initial reversible capacity and prevent the volume from changing $(\sim 30 \%)$ during electrochemical reactions. ${ }^{66)}$

\section{5. $\mathrm{Li}-\mathrm{Ti}-\mathrm{Nb}-\mathrm{O}$}

$\mathrm{LiTiNbO}_{5}$ (layered structure) was synthesized by Collin through the ion exchange method. ${ }^{67)}$ An electrode containing $0.8 \mathrm{~mol}$ of $\mathrm{Li}$ was found to have a charge/discharge cutoff range of $1.67\left(\mathrm{Li}\right.$ vs. $\mathrm{Li}^{+}$) and a capacitance value of $\sim 115 \mathrm{~mA} \mathrm{~h} \mathrm{~g}^{-1}$ in the first cycle. When the charge/discharge test was performed at a C-rate of $0.1, \mathrm{LiTiNbO}_{5}$ became a low cycle material due a capacity decrease to $\sim 90 \mathrm{~mA} \mathrm{~h} \mathrm{~g}^{-1}$ after 40 cycles.

\section{6. $\mathrm{Li}-\mathrm{Ti}-\mathrm{P}-\mathrm{O}$}

Cathode materials that are composed of $\mathrm{LiTi}_{2} \mathrm{P}_{3} \mathrm{O}_{12}$, which has a framework structure of NASICON (sodium superionic conductor) type have recently been studied using various synthesis methods. ${ }^{68)}$ As a result of electrochemical analysis, the main reduction and oxidation have been found to take place between 2.38 and $2.6 \mathrm{~V}$, and the material has been found to have a reversible capacity of $\sim 120 \mathrm{~mA} \mathrm{~h} \mathrm{~g}^{-1}$ at $0.1 \mathrm{C}$. These traits are similar to those of $\mathrm{TiP}_{2} \mathrm{O}_{7}$, and further research is necessary in order to lower the reaction potential by alloying and compounding this material with other materials.

\section{Part 2. Li-M-O Materials for Nuclear Fusion}

\section{Introduction}

Nuclear fusion is a phenomenon in which two light nuclei gather to form a single heavy nucleus. In order for nuclear fusion to take place, it is necessary to have a very high temperature and a large amount of energy that can separate the electrons from the atom. ${ }^{69)}$ Plasma is a hot ionized gas consisting of atoms with separate electrons and nuclei (ions); plasma is considered a fourth state of matter after solid, liquid, and gas. All plasmas are ionized, but that does not mean that all ionized gases are plasmas. In order to cre- 
ate a plasma, it is necessary to ionize deuterium and tritium (These isotopes are capable of nuclear fusion)..$^{70-72)}$

The following conditions are required for nuclear fusion:

1. Plasma at 100 million degrees Celsius

2. A device that can safely operate the plasma at 100 million degrees Celsius

3. Seawater, which is rich in deuterium (1 L of seawater contains about $0.03 \mathrm{~g}$ of deuterium)

As mentioned above, nuclear fusion involves using a magnetic field to confine a high-temperature (about 100 million degrees Celsius) plasma in a device called a "tokamak" to generate stable helium molecules, neutrons, and thermal energy after collisions between deuterium and tritium at high energy. ${ }^{73,74)}$ This device is expected to be a next-generation energy source that can generate electric energy. As a representative sample, there is the International Thermonuclear Experimental Reactor (ITER), which obtains energy from the D-T (Deuterium-Tritium) fusion reaction. ${ }^{75-77)}$ Fig. 11 shows the inner and outer fuel cycle of a fusion reactor.

$$
\mathrm{D}+\mathrm{T} \rightarrow{ }^{4} \mathrm{He}(3.5 \mathrm{MeV})+\mathrm{n}(14.1 \mathrm{MeV})
$$

In this case, "D" represents deuterium, "T" represents tritium, and "n" represents neutrons. In Korea, KSTAR (Korea Superconducting Tokamak Advanced Research) is a nuclear fusion research institute that has developed its own tokamak. $^{78)}$ In addition, there are various nuclear fusion research institutes such as the Jet program of the European Union, JT-60U in Japan, EAST in China, W-7X in Germany, the US TFTR, the TOCE-SUPRA of France, and the SST-1 of India.

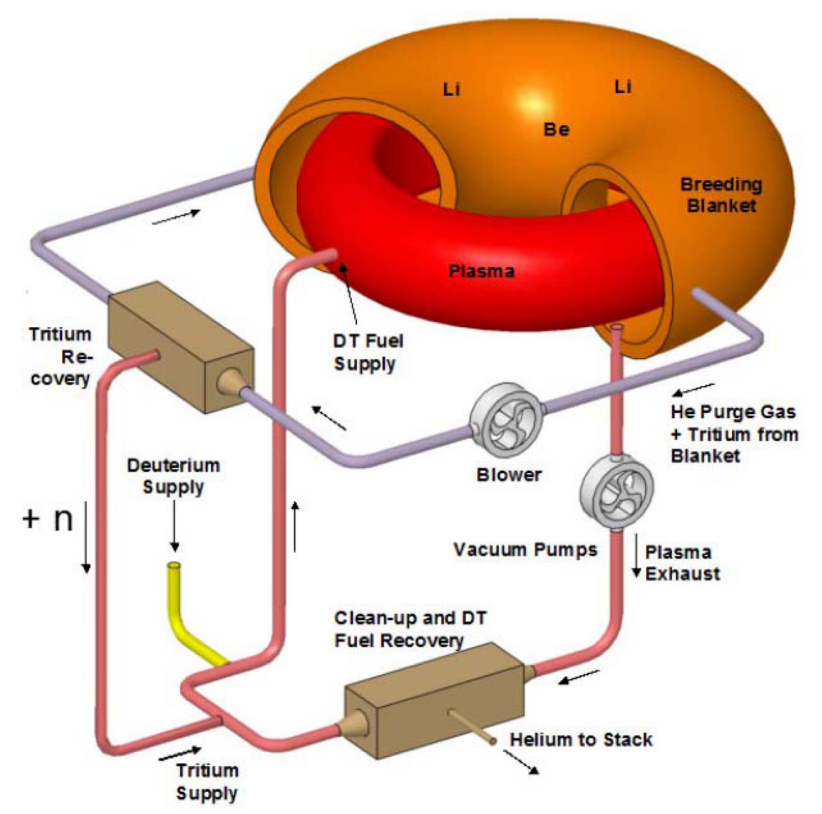

Fig. 11. Schematic diagram of fuel cycle system of nuclear fusion reactor. ${ }^{79}$
In a fusion reactor that uses a tokamak, there is a blanket that absorbs the generated neutrons. Inside the blanket, there is a tritium breeder, a ceramic material containing lithium, which produces tritium through a nuclear reaction of tritium breeders and neutrons. ${ }^{80,81)}$ This process is shown in the schematic diagram of the lithium transfer step of the solid breeder material, in Fig. 12.

$$
\begin{aligned}
& \mathrm{n}+{ }^{6} \mathrm{Li} \rightarrow \mathrm{T}+{ }^{4} \mathrm{He} \\
& \mathrm{n}+{ }^{7} \mathrm{Li} \rightarrow \mathrm{T}+{ }^{4} \mathrm{He}+\mathrm{n}
\end{aligned}
$$

Thus, the breeder of a nuclear fusion reactor is the key component in producing tritium; the role of lithium in the fusion reaction is to generate tritium via a nuclear reaction. Furthermore, the breeder must simultaneously convert nuclear energy to thermal energy while shielding the neutrons. ${ }^{83)}$ The tritium breeder should have the following conditions. $^{84,85)}$

1. It must contain a lot of lithium.

2. It must have high thermal conductivity and a low thermal expansion coefficient.

3. It must be mechanically and chemically stable.

4. The emission rate of tritium must be high

5 . The structure must be stable under irradiation

Materials those satisfy the conditions above include oxide ceramic materials such as $\mathrm{Li}_{2} \mathrm{O}, \mathrm{Li}_{2} \mathrm{TiO}_{3}, \mathrm{Li}_{2} \mathrm{ZrO}_{3}, \mathrm{LiAlO}_{2}$, and $\mathrm{Li}_{4} \mathrm{SiO}_{4}$, which are lithium-based compounds capable of generating tritium. ${ }^{86)}$

\section{Characteristics of Nuclear Fusion Materials}

$\mathrm{Li}_{2} \mathrm{O}$ has a high lithium atom density, high thermal conductivity, low tritium solubility, and high tritium growth rate, but has disadvantages such as high water reactivity and high lithium vapor pressure. ${ }^{87)} \mathrm{LiAlO}_{2}$ has a high melting point and low reactivity with water; it has a wide temperature range for use, and has excellent radiation properties, but has a poor tritium emission rate. ${ }^{88)} \mathrm{Li}_{4} \mathrm{SiO}_{4}$

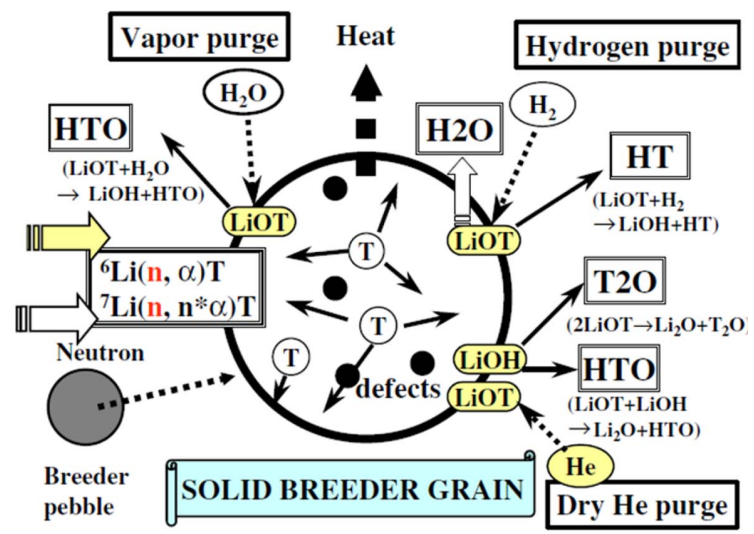

Fig. 12. Schematic diagram of the lithium transfer step in the solid breeder material. ${ }^{82)}$ 
has good tritium diffusivity and excellent chemical stability, but it is easily fragmented by radiation due to the anisotropy of its thermal expansion coefficient. ${ }^{89)} \mathrm{Li}_{2} \mathrm{ZrO}_{3}$ is chemically and mechanically stable and has a high tritium emission rate, but there is an issue of zirconium becoming excited when heat is radiated after irradiation. ${ }^{90)}$ Among researchers, $\mathrm{Li}_{2} \mathrm{TiO}_{3}$ became a popular material as a breeder due to its excellent maneuverability of tritium, its chemical stability, and its low activation energy. ${ }^{91,92)}$ The physical properties of these lithium-based oxides are closely related to their physical properties such as their porosity, particle size, particle shape, and microstructure. Therefore, optimization of the manufacturing process of breeders plays an important role in controlling the physical properties. Since the characteristics of the initial powder in the preparation of an oxide sintered body have great influence on the physical properties of the sintered body, optimization of the initial powder plays a very important role in the manufacturing process. ${ }^{93)}$ In addition, the breeder is present in the form of pebbles; these pebbles can easily relax the thermoadaptive force morphologically, and reduce the possibility of cracking and swelling due to irradiation. ${ }^{94,95)}$ In terms of TBR (Tritium breeding ratio), pebbles should have spherical shapes of about $1 \mathrm{~mm}$ diameter or more, and should have enough strength to maintain a certain density. Fig. 13 shows $\mathrm{TiO}_{2}$ Pebbles (Used to make $\mathrm{Li}_{2} \mathrm{TiO}_{3}$ Pebbles) before rolling process, after $6 \mathrm{~h}$ of rolling process, and after $20 \mathrm{~h}$ of rolling process. With the increased rolling time, the pebbles became spherical.

Since the porosity has an important influence on the heat conductivity of the pebbles, it is important for the breeder to have an appropriate porosity. ${ }^{97,98)}$ In order to synthesize various tritium breeders, a variety of methods are being used to produce powders. ${ }^{99)}$ Generally, a high-temperature solid phase method and a high-energy ball mill method in which calcination and sintering proceed through a mixing process among ceramic manufacturing methods are used. Recently, liquid phase methods such as hydrothermal synthesis, the sol-gel process, the precipitation method, the hydrolysis method, the precipitation method, and the micro-emulsion method have also been used. When the liquid phase method is used, a fine powder with high purity can be obtained, and the composition and particle size of the product can be controlled. NFRI Korea ITER and the Material Development Department of KAERI are pursuing world trends by focusing the research direction of the nuclear fusion tritium breeder on the ITER DEMO. In Korea, research and development is mainly focused on $\mathrm{Li}_{2} \mathrm{TiO}_{3}$ through the ITER project at NFRI. However, KSTAR's research has been mainly focused on tritium breeders composed of lithium oxide, and there has not been much progress. In order to develop domestic technology such as KSTAR in the future, it will be necessary to conduct research on breeders through various synthesis methods and optimization. It will be possible for Korea to join the ranks of the advanced countries once Korea acquires essential nuclear fusion technology.
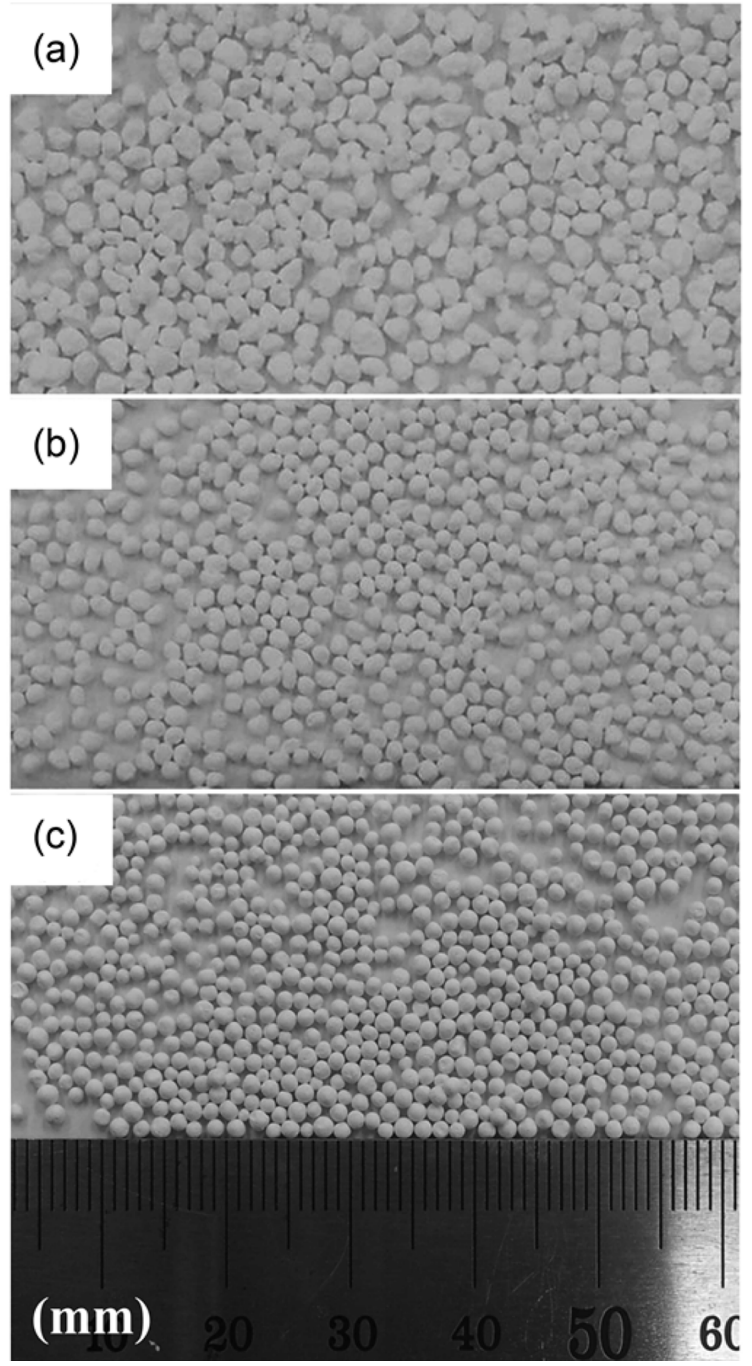

Fig. 13. (a) $\mathrm{TiO}_{2}$ Pebbles (Used to make $\mathrm{Li}_{2} \mathrm{TiO}_{3}$ Pebbles) before rolling process, (b) after $6 \mathrm{~h}$ of rolling process, (c) after 20 hours of rolling process. $\left.{ }^{96}\right)$

\section{Acknowledgments}

This research was supported by the National R\&D Program through the National Research Foundation of Korea (NRF), funded by the Ministry of Science, ICT and Future Planning (NRF-2015M1A7A1A02002288).

\section{REFERENCES}

1. M. S. Islam and C. A. J. Fisher, "Lithium and Sodium Battery Cathode Materials: Computatianal Insights into Voltage, Diffusion and Nanostructural Properties," Chem. Soc. Rev., 43 [1] 185-204 (2014).

2. H. J Kim, U. C. Chung, Y. U. Jeong, J. H. Lee, and J. J. Kim, "Crystal Structures, Electrical Conductivities and Electrochemical Properties of $\mathrm{LiCo}_{1-\mathrm{X}} \mathrm{Mg}_{\mathrm{x}} \mathrm{O}_{2}(\mathrm{x}=0.03)$ for Secondary Lithium Ion Batteries," J. Korean Ceram. Soc., 42 [9] 602-6 (2005). 
3. K. Mizushima, P. C. Jones, P. J. Wiseman, and J. B. Goodenough, " $\mathrm{Li}_{\mathrm{x}} \mathrm{CoO}_{2}(0<\mathrm{x}<1)$ : A New Cathode Materials for Batteries of High Energy Density," Mat. Res. Bull., 15 [6] 783-89 (1980).

4. S. H. Kim, K. B. Shim, J. P. Ahn, and C. S. Kim, "Structural Stability during Charge-Discharge Cycles in ZrDoped $\mathrm{LiCoO}_{2}$ Powders," J. Korean Ceram. Soc., 45 [3] 167$171(2008)$

5. C. M. Julien, A. Mauger, K. Zaghib, and H. Groult, "Comparative Issues of Cathode Materials for Li-Ion Batteries," Inorganics, 2 [1] 132-54 (2014).

6. M. S. Whittingham, "Lithium Batteries and Cathode Materials," Chem. Rev., 104 [10] 4271-301 (2004).

7. T. Ohzuku, M. Kitakawa, and T. Hirai, "Electrochemistry of Manganese Dioxide in Lithium Nonaqueous Cell III. XRay Diffractional Study on the Reduction of Spinel-Related Manganese Dioxide," J. Electrochem. Soc., 137 [3] 769-75 (1990).

8. D. H. Jang, Y. J. Shin, and S. M. Oh, "Dissolution of Spinel Oxides and Capacity Losses in $4 \mathrm{~V} \mathrm{Li} / \mathrm{LixMn}_{2} \mathrm{O}_{4}$ Cells," $J$. Electrochem. Soc., 143 [7] 2204-11 (1996).

9. T. Inoue and M. Sano, "An Investigation of Capacity Fading of Manganese Spinels Stored at Elevated Temperature,” J. Electrochem. Soc., 145 [11] 3704-7 (1998).

10. Y. Xia and M. Yoshio, "An Investigation of Lithium Ion Insertion into Spinel Structure Li-Mn-O Compound," J. Electrochem. Soc., 143 [3] 825-33 (1996).

11. Y. Xia, T. Sakai, T. Fujieda, X. Yang, X. Sun, Z. Ma, J. McBreen, and M. Yoshio, "Correlating Capacity Fading and Structural Changes in $\mathrm{Li}_{1+\mathrm{x}} \mathrm{Mn}_{2 \cdot \mathrm{y}} \mathrm{O}_{4}$. Spinel Cathode Material: A Systematic Study on the Effects of Li/Mn Ratio and Oxygen Deficiency," J. Electrochem. Soc., 148 [7] 72329 (2001).

12. M. M. Thackeray, Y. S. Horn, A. J. Kahian, K. D. Kepler, E. Skinner, J. T. Vaughey, and S. A. Hackney, "Structural Fatigue in Spinel Electrodes in High Voltage (4 V) Li/ $\mathrm{Li}_{\mathrm{x}} \mathrm{Mn}_{2} \mathrm{O}_{4}$ Cells," Electrochem. Soc. Solid-State Lett., 1 [1] 7 9 (1998).

13. A. K. Padhi, K. S. Nanjundaswamy, and J. B. Goodenough, "Phospho-Olivines as Positive-Electrode Materials for Rechargeable Lithium Batteries," J. Electrochem. Soc., 144 [4] 1188-94 (1997).

14. S. Y. Chung, J. T. Bloking, and Y. M. Chiang, "Electronically Conductive Phospho-olivines as Lithium Storage Electrodes," Nat. Mater., 1 [2] 123-28 (2002).

15. W. Ojczyk, J. Marzec, K. Swierczek, W. Zajac, M. Molenda, R. Dziembaj, and J. Molenda, "Studies of Selected Synthesis Procedures of the Conducting $\mathrm{LiFePO}_{4}$-Based Composite Cathode Materials for Li-Ion Batteries," J. Power Sources, 173 [2] 700-6 (2007).

16. H. Liu, J. Xie, and K. Wang, "Synthesis and Characterization of $\mathrm{LiFePO}_{4} /\left(\mathrm{C}+\mathrm{Fe}_{2} \mathrm{P}\right)$ Composite Cathodes," Solid State Ionics, 179 [27] 1768-71 (2008).

17. Y. Lin, M. X. Gao, D. Zhu, Y. F. Liu, and H. G. Pan, "Effects of Carbon Coating and Iron Phosphides on the Electrochemical Properties of $\mathrm{LiFePO}_{4} / \mathrm{C}$," J. Power Sources, 184 [2] 444-48 (2008).

18. H. Liu and D. Tang, "The Low Cost Synthesis of Nanoparticles $\mathrm{LiFePO}_{4} / \mathrm{C}$ Composite for Lithium Rechargeable Bat- teries," Solid State Ionics, 179 [33] 1897-901 (2008).

19. B. W. Kang and G. Ceder, "Battery Materials for Ultrafast Charging and Discharging," Nature, 458 [7235] 190-93 (2009)

20. N. Yabuuchi and T. Ohzuku, "Novel Lithium Insertion Material of $\mathrm{LiCo}_{1 / 3} \mathrm{Ni}_{1 / 3} \mathrm{Mn}_{1 / 3} \mathrm{O}_{2}$ for Advanced Lithium-ion Batteries,” J. Power Sources, 119-121 171-74 (2003).

21. R. H. Shin, S. I. Son, S. M. Lee, Y. S. Han, Y. D. Kim, and S. S. Ryu, "Effect of $\mathrm{Li}_{3} \mathrm{BO}_{3}$ Additive on Densification and Ion Conductivity of Garnet-Type $\mathrm{Li}_{7} \mathrm{La}_{3} \mathrm{ZrO}_{12}$ Solid Electrolytes of All-Solid-State Lithium-Ion Batteries," J. Korean Ceram. Soc., 53 [1] 712-718 (2016).

22. I. Y. Kim, S. H. Jee, and Y. S. Yoon "High-Speed Deposited Amorphous Li-B-W-O Thin Film Electrolytes for AllSolid-State Batteries," Sci. Adv. Mater., 8 [1] 96-102 (2016).

23. Y. Zhao and L. L. Daemen, "Superionic Conductivity in Lithium-Rich Anti-Perovskites," J. Am. Chem. Soc., 134 [36] 15042-47 (2012).

24. A. Emly, E. Kioupakis, and A. V. Ven. "Phase Stability and Transport Mechanisms in Antiperovskite $\mathrm{Li}_{3} \mathrm{OCl}$ and $\mathrm{Li}_{3} \mathrm{OBr}$ Superionic Conductors," Chem. Mater., 25 [23] 4663-70 (2013).

25. F. Lalère, J. B. Lerichea, M. Courty, S. Boulineau, V. Viallet, C. Masquelier, and V. Seznec, "An All-Solid State NASICON Sodium Battery Operating at $200^{\circ} \mathrm{C}$," J. Power Sources, 247 975-80 (2014).

26. J. C. Bachman, S. Muy, A. Grimaud, H. S. Chang, N. Pour, S. F. Lux, O. Paschos, F. Maglia, S. Lupart, P. Lamp, L. Giordano, and Y. S. Horn, "Inorganic Solid-State Electrolytes for Lithium Batteries: Mechanisms and Properties Governing Ion Conduction," Chem. Rev., 116 [1] 140-62 (2016).

27. I. Kokal, Solid State Electrolytes for All Solid State 3D Lithium ion Batteries, pp. 9-34, in Ph.D. Thesis, Eindhoven University of Technology, Eindhoven, 2012.

28. H. B Kang, N. H. Cho, and Y. H. Kim, "Effects of HeatTreatment Condition on the Characteristics of Sintering and Electrical Behaviors of Two NASICON Compounds," J. Korean Ceram. Soc., 34 [7] 685-92 (1997).

29. H. El-Shinawi, C. Greaves, and J. Janek, "Sol-Gel Synthesis and Room-Temperature Properties of $\alpha$-LiZr $2\left(\mathrm{PO}_{4}\right)_{3}$," $R S C$ Adv., 5 [22] 17054-59 (2015).

30. K. M. Kim, D. O. Shin, and Y. G. Lee, "Effects of Preparation Conditions on the Ionic Conductivity of Hydrothermally Synthesized $\mathrm{Li}_{1+\mathrm{x}} \mathrm{Al}_{\mathrm{x}} \mathrm{Ti}_{2-\mathrm{x}}\left(\mathrm{PO}_{4}\right)_{3}$ Solid Electrolytes," Electrochim. Acta, 176 1364-73 (2015).

31. K. Arbi, W. Bucheli, R. Jiménez, and J. Sanz, "High Lithium ion Conducting Solid Electrolytes based on NASICON $\mathrm{Li}_{1+\mathrm{x}} \mathrm{Al}_{\mathrm{x}} \mathrm{M}_{2-\mathrm{x}}\left(\mathrm{PO}_{4}\right)_{3}$ Materials $(\mathrm{M}=\mathrm{Ti}$, Ge and $0 \leq \mathrm{x} \leq 0.5)$," $J$. Eur. Ceram. Soc., 35 [5] 1477-84 (2015).

32. K. Arbi, S. Mandal, J. M. Rojo, and J. Sanz, "Dependence of Ionic Conductivity on Composition of Fast Ionic Conductors $\mathrm{Li}_{1+\mathrm{x}} \mathrm{Ti}_{2-\mathrm{x}} \mathrm{Al}_{\mathrm{x}}\left(\mathrm{PO}_{4}\right)_{3}, 0 \leq \mathrm{x} \leq 0.7$. A Parallel NMR and Electric Impedance Study," Chem. Mater., 14 [3] 1091-97 (2002).

33. D. H. Kothari and D. K. Kanchan, "Effect of Doping of Trivalent Cations $\mathrm{Ga}^{3+}, \mathrm{Sc}^{3+}, \mathrm{Y}^{3+}$ in $\mathrm{Li}_{1.3} \mathrm{Al}_{0.3} \mathrm{Ti}_{1.7}\left(\mathrm{PO}_{4}\right)_{3}$ (LATP) System on $\mathrm{Li}^{+}$Ion Conductivity," Phys. B, 501 90-4 (2016).

34. H. Aono, E. Sugimoto, Y. Sadaoka, N. Imanaka, and G. Y. Adachi, "Ionic Conductivity of Solid Electrolytes Based on 
Lithium Titanium Phosphate," J. Electrochem. Soc., 137 [4] 1023-27 (1990).

35. X. L. Wu, J. Zong, H. Xu, W. Wang, and X. J. Liu, "Effects of LAGP Electrolyte on Suppressing Polysulfide Shuttling in Li-S Cells," RSC Adv., 6 [62] 57346-56 (2016).

36. D. Rettenwander, C. A. Geiger, M. Tribus, P. Tropper, and G. Amthauer, "A Synthesis and Crystal Chemical Study of the Fast Ion Conductor $\mathrm{Li}_{7-3 \mathrm{x}} \mathrm{Ga}_{\mathrm{x}} \mathrm{La}_{3} \mathrm{Zr}_{2} \mathrm{O}_{12}$ with $\mathrm{x}=0.08$ to 0.84," Inorg. Chem., 53 [12] 6264-69 (2014).

37. N. C. R.-Navarro, T. Yamashita, A. Miura, M. Higuchi, and K. Tadanaga, "Effect of Sintering Additives on Relative Density and Li-Ion Conductivity of $\mathrm{Nb}$-Doped $\mathrm{Li}_{7} \mathrm{La}_{3} \mathrm{ZrO}_{12}$ Solid Electrolyte," J. Am. Ceram. Soc., 100 [1] 276-85 (2017).

38. R. Murugan, V. Thangadurai, and W. Weppner, "Fast Lithium Ion Conduction in Garnet-Type $\mathrm{Li}_{7} \mathrm{La}_{3} \mathrm{Zr}_{2} \mathrm{O}_{12}$ " Angewandte Chemie., 46 [41] 7778-81 (2007).

39. J. Awaka, N. Kijima, H. Hayakawa, and J. Akimoto, "Synthesis and Structure Analysis of Tetragonal $\mathrm{Li}_{7} \mathrm{La}_{3} \mathrm{Zr}_{2} \mathrm{O}_{12}$ with the Garnet-Related Type Structure," J. Solid State Chem., 182 [8] 2046-52 (2009).

40. Y. Jin and P. J. McGinn, "Al-Doped $\mathrm{Li}_{7} \mathrm{La}_{3} \mathrm{Zr}_{2} \mathrm{O}_{12}$ Synthesized by a Polymerized Complex Method," J. Power Sources, 196 [20] 8683-87 (2011).

41. H. El-Shinawi, G. W. Paterson, D. A. MacLaren, E. J. Cussen, and S. A. Corr, "Low-Temperature Densification of Aldoped $\mathrm{Li}_{7} \mathrm{La}_{3} \mathrm{Zr}_{2} \mathrm{O}_{12}$ : a Reliable and Controllable Synthesis of Fast-ion Conducting Garnets," J. Mater. Chem. A, 5 [1] 319-29 (2017).

42. Y. Jiang, X. Zhu, S. Qin, M. Ling, and J. Zhu, "Investigation of $\mathrm{Mg}^{2+}, \mathrm{Sc}^{3+}$ and $\mathrm{Zn}^{2+}$ Doping Effects on Densification and Ionic Conductivity of Low-Temperature Sintered $\mathrm{Li}_{7}$ $\mathrm{La}_{3} \mathrm{Zr}_{2} \mathrm{O}_{12}$ Garnets," Solid State Ionics, 300 73-7 (2017).

43. S. Song, D. Sheptyakov, A. M. Korsunsky, H. M. Duong, and L. Lua, "High Li Ion Conductivity in a Garnet-Type Solid Electrolyte via Unusual Site Occupation of the Doping Ca Ions," Mater. Des., 93 232-37 (2016).

44. P. G. Bruce and A. R. West, "Ionic Conductivity of LISICON Solid Solutions, $\mathrm{Li}_{2+2 \mathrm{x}} \mathrm{Zn}_{1-\mathrm{x}} \mathrm{GeO}_{4}$, J. Solid State Chem., 44 [3] 354-65 (1982).

45. S. Hori, M. Kato, K. Suzuki, M. Hirayama, Y. Kato, and R. Kanno, "Phase Diagram of the $\mathrm{Li}_{4} \mathrm{GeS}_{4}-\mathrm{Li}_{3} \mathrm{PS}_{4}$ QuasiBinary System Containing the Superionic Conductor $\mathrm{Li}_{10} \mathrm{GeP}_{2} \mathrm{~S}_{12}$, J. Am. Ceram. Soc., 98 [10] 3352-60 (2015).

46. P. Zhou, J. Wang, F. Cheng, F. Li, and J. Chen, "A Solid Lithium Superionic Conductor $\mathrm{Li}_{11} \mathrm{AlP}_{2} \mathrm{~S}_{12}$ with a ThioLISICON Analogous Structure," Chem. Commun., 52 [36] 6091-94 (2016).

47. R. Kanno and M. Murayama, "Lithium Ionic Conductor Thio-LISICON: The $\mathrm{Li}_{2} \mathrm{~S} \mathrm{GeS}_{2} \mathrm{P}_{2} \mathrm{~S}_{5}$ System," J. Electrochem. Soc., 148 [7] A742-46 (2001).

48. Y. Inaguma, L. Chen, M. Itoh, and T. Nakamura, "Candidate Compounds with Perovskite Structure for High Lithium Ionic Conductivity," Solid State Ionics, 70 196-202 (1994).

49. S. Garc'ia-Mart'ina, J. M. Rojob, H. Tsukamotoc, E. Mora'na, and M. A. Alario-Francoa, "Lithium-Ion Conductivity in the Novel $\mathrm{La}_{1 / 3-\mathrm{x}} \mathrm{Li}_{3 \mathrm{x}} \mathrm{NbO}_{3}$ Solid Solution with Perovskite-Related Structure," Solid State Ionics, 116 [1] 11-8
(1999).

50. L. Latie, G. Villeneuve, D. Conte, and G. Le Flem, "Ionic Conductivity of Oxides with General Formula $\mathrm{Li}_{\mathrm{x}} \mathrm{Ln}_{1 / 3} \mathrm{Nb}_{1-}$ ${ }_{x} \mathrm{Ti}_{\mathrm{x}} \mathrm{O}_{3}(\mathrm{Ln}=\mathrm{La}, \mathrm{Nd})$, , J. Solid State Chem., 51 [3] 293-99 (1984).

51. A. G. Belous, G. N. Novitskaya, S. V. Polyanetskaya, and Y. I. Gornikon, "Investigation into Complex Oxides of $\mathrm{La}_{2 / 3}$ ${ }_{\mathrm{x}} \mathrm{Li}_{3 \mathrm{x}} \mathrm{TiO}_{3}$ Composition,” Izv. Akad. Nauk SSSR, Neorg. Mater., 23 [3] 470-72 (1987).

52. X. Lu "Effect of Microstructure on the Mechanical, Thermal, and Electronic Property Measurement of Ceramic Coatings," Int. J. Miner. Metall. Mater., 21 [11] 1127-31 (2014).

53. C. W. Ban and G. M. Choi, "The Effect of Sintering on the Grain Boundary Conductivity of Lithium Lanthanum Titanates," Solid State Ionics, 140 [3] 285-92 (2001).

54. M. Itoh, Y. Inaguma, W. H. Jung, L. Chen, and T. Nakamura, "High Lithium Ion Conductivity in the Perovskite-type Compounds $\mathrm{Ln}_{1 / 2} \mathrm{Li}_{1 / 2} \mathrm{TiO}_{3}(\mathrm{Ln}=\mathrm{La}, \mathrm{Pr}, \mathrm{Nd}$, Sm)," Solid State Ionics, 70 203-7 (1994).

55. G. Schwering, A. Honerscheid, L. Wullen, and M. Jansen, "High Lithium Ionic Conductivity in the Lithium Halide Hydrates $\mathrm{Li}_{3-\mathrm{n}}\left(\mathrm{OH}_{\mathrm{n}}\right) \mathrm{Cl}(0.83 \leq \mathrm{n} \leq 2)$ and $\mathrm{Li}_{3-\mathrm{n}}\left(\mathrm{OH}_{\mathrm{n}}\right) \mathrm{Br}(1 \leq \mathrm{n}$ $\leq 2)$ at Ambient Temperatures," Chem. Phys. Chem., 4 [4] 343- 48 (2003).

56. M. H. Braga, J. A. Ferreira, V. Stockhausen, J. E. Oliveira, and A. El-Azab, "Novel $\mathrm{Li}_{3} \mathrm{ClO}$ based Glasses with Superionic Properties for Lithium Batteries," Mater. Chem. A, 2 [15] 5470-80 (2014).

57. Z. Lu, C. Chen, Z. M Baiyee, X, Chen, C. Niu, and F. Ciucci, "Defect Chemistry and Lithium Transport in $\mathrm{Li}_{3} \mathrm{OCl}$ Antiperovskite Superionic Conductors," Phys. Chem. Chem. Phys., 17 [48] 32547-55 (2015).

58. M. Bilal, S. J. Asadabadi, R. Ahmad, and I. Ahmad, "Electronic Properties of Antiperovskite Materials from State-ofthe-Art Density Functional Theory," J. Chem., 2015 1-11 (2015).

59. K. S. Lee, S. Y. Shin, and Y. S. Yoon, " $\mathrm{Fe}_{3} \mathrm{O}_{4}$ Nanoparticles on MWCNTs Backbone for Lithium Ion Batteries," $J$. Korean Ceram. Soc., 53 [3] 376-80 (2016).

60. M. V. Reddy, G. V. Subba Rao, and B. V. R. Chowdari, "Metal Oxides and Oxysalts as Anode Materials for Li Ion Batteries," Chem. Rev., 113 [7] 5364-457 (2013).

61. W. J. Zhang, "A Review of the Electrochemical Performance of Alloy Anodes for Lthium-Ion Batteries," J. Power Sources, 196 [1] 13-24 (2011).

62. H. G. Jung, S. T. Myung, C. S. Yoon, S. B. Son, K. H. Oh, K. Amine, B. Scrosati, and Y. K. Sun, "Microscale Sherical Crbon-Cated $\mathrm{Li}_{4} \mathrm{Ti}_{5} \mathrm{O}_{12}$ as Urahigh Power Anode Material for Lithium Batteries," Energy Environ. Sci., 4 1345-51 (2011).

63. M. Wakihara, Y. Kadoma, N. Kumagai, H. Mita, R Araki, K. Ozawa, and Y. Ozawa, "Development of Nonflammable Lithium Ion Battery using a New All-Solid Polymer Electrolyte," J. Solid State Electrochem.. 16 [3] 847-55 (2012).

64. B. Tian, H. Xiang, L. Zhang, Z. Li, and H. Wang, "Niobium Doped Lithium Titanate as a High Rate Anode Material for Li-ion Batteries," Electrochim. Acta, 55 [19] 5453-58 (2010). 65. Y. Takeda, M. Nishijima, M. Yamahata, K. Takeda, N. 
Imanishi and O. Yamamoto, "Lithium Secondary Batteries Using a Lithium Cobalt Nitride, $\mathrm{Li}_{2.6} \mathrm{Co}_{0.4} \mathrm{~N}$, as the Anode," Solid State Ionics, 130 61-9 (2000).

66. N. S. Choi, J. S. Yin, R. Z. Kim, and S. S. Kim, "Electrochemical Properties of Lithium Vanadium Oxide as an Anode Material for Lithium-ion Battery," Mater. Chem. Phys., 116 [2] 603-6 (2009).

67. J. F. Colin, V. P. V. Caignaert, M. Hervieu, and B. Raveau, "A Novel Layered Titanoniobate LiTiNbO $_{5}$ : Topotactic Synthesis and Electrochemistry Versus Lithium," Inorg. Chem., 45 [18] 7217-23 (2006).

68. Z. X. Lin, H. J. Yu, S. C. Li, and S. B Tian, "Lithium ion Conductors based on $\mathrm{LiTi}_{2} \mathrm{P}_{3} \mathrm{O}_{12}$ Compound," Solid State Ionics, 31 [2] 91-4 (1988).

69. R. E. H. Clark, and D. H. Reiter, Nuclear Fusion Research: Understanding Plasma- Surface Interactions; Vol. 78, pp. 3-26, Springer, Berlin, 2005.

70. R. Kodama, H. Shiraga, K. Shigemori, Y. Toyama, S. Fujioka, H. Azechi, H. Fujita, H. Habara, T. Hall, Y. Izawa, T. Jitsuni, Y. Kitagawa, K. M. Krushelnick, K. L. Lancaster, K. Mima, K. Nagai, M. Nakai, H. Nishimura, T. Norimatsu, P. A. Norreys, S. Sakabe, K. A. Tanaka, A. Youssef, M. Zepf, and T. Yamanaka, "Nuclear Fusion: Fast Heating Scalable to Laser Sufion Ignition," Nature, 418 [6901] 933-34 (2002).

71. P. C. Stangeby and G. M. McCracken, "Plasma Boundary Phenomena Ion Tokamaks," Nucl. Fusion, 30 [7] 1225 (1990).

72. B. LaBombard, J. E. Rice, A. E. Hubbard, J. W. Hughes, M. Greenwald, J. Irby, Y. Lin, B. Lipschultz, E. S. Marmar, and C. S. Pitcher, "Transport-Driven Scrape-Off-Layer Flows and the Boundary Conditions Imposed at the Magnetic Separatrix in a Tokamak Plasma," Nucl. Fusion, 44 [10] 1047 (2004).

73. P. N. Yushmanov, T. Takizuka, K. S. Riedel, O. J. W. F. Kardaun, J. G. Cordey, S. M. Kaye, and D. E. Post, "Scalings for Tokamak Energy Confinement," Nucl. Fusion, 30 [10] 1999 (1990).

74. M. N. Rosenbluth and S. V. Putvinski, "Theory for Avalanche of Runaway Electrons in Tokamaks," Nucl. Fusion, 37 [10] 1355 (1997).

75. N. Taylor and P. Cortes, "Lessons Learnt from ITER Safety \& Licensing for DEMO and Future Nuclear Fusion Facilities," Fusion Eng. Des., 89 [9-10] 1995-2000 (2014).

76. F. J. Casson, E. Poli, C. Angioni, R. Buchholz, and A. G. Peeters, "Effect of Turbulence on Electron Cyclotron Current Drive and Heating in ITER," Nucl. Fusion, 55 [1] 012002 (2015).

77. D. W. Lee, B. G. Hong, Y. H. Kim, W. K. In, and K. H. Yoon, "Preliminary Design of a Helium Cooled Molten Lithium test Blanket Module for the ITER Test in Korea," Fusion Eng. Des., 82 [4] 381-88 (2007).

78. G. S. Lee, J. Kim, S. M. Hwang, C. S. Chang, H. Y. Chang, M. H. Cho, B. H. Choi, K. Kim, K. W. Cho, and S. Cho, "The KSTAR Project: An Advanced Steady State Superconducting Tokamak Experiment," Nucl. Fusion, 40 [3Y] 575 (2000).

79. M. Glugla, D. Babineau, L. Bo, S. Maruyama, R. Pearce, G. Piazza, B. Rogers, S. Willms, T. Yamanishi, and S. H. Yun,
"Review of the ITER D-T Fuel Cycle Systems and Recent Progress"; pp. 24-9 in 9th International Conference on Tritium Science and Technology. Tritium, Japan, 2010.

80. H. Kawamura, E. Ishitsuka, K. Tsuchiya, M. Nakamichi, M. Uchida, H. Yamada, K. Nakamura, H. Ito, T. Nakazawa, and H. Takahashi, "Development of Advanced Blanket Materials for a Solid Breeder Blanket of a Fusion Reactor," Nucl. Fusion, 43 [8] 675 (2003).

81. M. Enoeda, Y. Kosaku, T. Hatano, T. Kuroda, N. Miki, T. Honma, M. Akiba, S. Konishi, H. Nakamura, and T. Kawamura, "Design and Technology Development of Solid Breeder Blanket Cooled by Supercritical Water in Japan," Nucl. Fusion, 43 [12] 1837 (2003).

82. M. Nishikawa, T. Kinjyo, T. Ishizaka, S. Beloglazov, T. Takeishi, M. Enodeda, and T. Tanifuji, "Release Behavior of Bred Tritium from $\mathrm{LiAlO}_{2}$," J. Nucl. Mater., 335 [1] 70-6 (2004).

83. A. R. Raffray, M. Akiba, V. Chuyanov, L. Giancarli, and S. Malang, "Breeding Blanket Concepts for Fusion and Materials Requirements," J. Nucl. Mater., 307 21-30 (2002).

84. J. G. van der Laan, H. Kawamura, N. Roux, and D. Yamaki, "Ceramic Breeder Research and Development: Progress and Focus," J. Nucl. Mater., 283 99-109 (2000).

85. C. E. Johnson, "Ceramic Breeder Materials," Ceram. Int., 17 [4] 253-58 (1991).

86. G. W. Hollenberg, "Fast Neutron Irradiation Results on $\mathrm{Li}_{2} \mathrm{O}, \mathrm{Li}_{4} \mathrm{SiO}_{4}, \mathrm{Li}_{2} \mathrm{ZrO}_{3}$ and $\mathrm{LiAlO}_{2}$, J. Nucl. Mater., 123 [13] 896-900 (1984).

87. J. L. Ethridge and D. E. Baker, "Effects of Fast Neutron Irradiation on Thermal Conductivity of $\mathrm{Li}_{2} \mathrm{O}$ and $\mathrm{LiAlO}_{2}$," J. Am. Ceram. Soc., 71 [6] C294-96 (1988).

88. J. Kin, Z. Wen, X. Xu, N. Li, and S. Song, "Characterization and Improvement of Water Compatibility of $\mathrm{Y}-\mathrm{LiAlO}_{2}$ Ceramic Breeders," Fusion Eng. Des., 85 [7-9] 1162-66 (2010)

89. J. Han, X. Gao, Y. Gong, X. Chen, and C. T. Yang, "Fabrication of a $\mathrm{Li}_{4} \mathrm{SiO}_{4}$-Pbtritium Breeding Material," Fusion Eng. Des., 89 [12] 3046-53 (2014).

90. L. Guo, X. Wang, S. Zhang, C. Zhong, and L. Li, "Effect of Alkalinity on the Hydrothermal Synthesis of $\mathrm{Li}_{2} \mathrm{ZrO}_{3} \mathrm{Nano}$ Tube Arrays," J. Mater. Sci., 46 6960-63 (2011).

91. Y. H. Park, S. Y. Cho, and M. Y. Ahn, "Fabrication of $\mathrm{Li}_{2}$ $\mathrm{TiO}_{3}$ Pebbles Using PVA-Boric Acid Reaction for Solid Breeding Materials," J. Nucl. Mater., 455 [1-3] 106-10 (2014).

92. K. M. Min, Y. H. Park, and S. Y. Cho, "Synthesis of $\mathrm{Li}_{2} \mathrm{TiO}_{3}$ Powder with High Crystalline Structure for Tritium Breeding Material by Ion-Exchange Process," Fusion Eng. Des., 109 326-29 (2016).

93. C. E. Johnson, "Tritium Behavior in Lithium Ceramics," J. Nucl. Mater., 270 [1-2] 212-20 (1999).

94. P. Gierszewski, M. Dalle Donne, H. Kawamura, and M. Tillack, "Ceramic Pebble Bed Development for Dusion Blankets," Fusion Eng. Des., 27 167-78 (1995).

95. G. Piazza, J. Reimann, E. Gunther, R. Knitter, N. Roux, and J. D. Lulewicz, "Characterization of Ceramic Breeder Materials for the Helium Cooled Pebble Bed Blanket," J. Nucl. Mater., 307 811-16 (2002).

96. M. W. Yu, Y. H. Park, and S. J. Lee, "Fabrication of $\mathrm{Li}_{2} \mathrm{TiO}_{3}$ 
Pebbles by Lithium Solution Penetration Method," $J$. Korean Ceram. Soc., 50 [5] 333-40 (2013).

97. G. Dell'Orco, A. Ancona, A. Dimaio, M. Simoncini, and G. Vella, "Thermo-Mechanical Testing of Li-Ceramic for the Helium Cooled Pebble Bed (HCPB) Breeding Blanket," J. Nucl. Mater., 329 1305-8 (2004).
98. A. Abou-Sena, A. Ying, and M. Abdou, "Effective Thermal Conductivity of Lithium Ceramic Pebble Beds for Fusion Blankets: A Review," Fusion Sci. Technol., 47 [4] 1094-100 (2005).

99. J. Ongena and Y. Ohawa, "Nuclear Fusion: Status Report and Future Prospects," Energ. Policy, 96 770-78 (2016). 